\title{
Explaining the Changes of Income Distribution in China
}

\author{
by \\ Lixin Colin $\mathrm{Xu}$ \\ Development Research Group, the World Bank, USA \\ Heng-fu Zou ${ }^{1}$ \\ Guanghua School of Management, Peking University, China \\ Institute for Advanced Study, Wuhan University, China \\ Development Research Group, the World Bank, USA
}

Revised, May 2000

\begin{abstract}
China has experienced one of the most remarkable increase in inequality over the last decade: the Gini coefficient increasing from 25.7 in 1984 to 37.8 in 1992 . Using the recent developments in the theory of income distribution (Benerjee and Newman, 1993; Galor and Zeira, 1993) and a new panel data set about Chinese provincial-urban-level income inequality, this paper finds that inequality increased with the reduction of the share of state-owned enterprises in GDP, high inflation, growth, and (less significantly) the increasing exposure to foreign trade. We also find some evidence for the Director's Law: income redistribution tends to

\footnotetext{
1 Mailing address: Dr. Heng-fu Zou, The World Bank, MC2-611, 1818 H St. NW, Washington, DC 20433, USA; Tel. (202) 473-7939; Fax (202) 522-1154; Email: Hzou@worldbank.org. For data, comments, and help, the authors are grateful to Tamar Manuelyan, Xiaoqing Yu, Tao Zhang, and Shaohua Chen.
} 
shift resources from the rich and the poor to the middle class. We do not find schooling and urbanization to be a significant explanatory factor.

\section{Introduction}

Among many developed countries, Atkinson (1997) has noticed the unparalleled rise in United Kingdom income inequality in the 1980s:

"In the United States, the Gini coefficient of inequality for household income rose between 1968 and 1992 by three and a half percentage points.... This is a significant increase, but if you want to see a big increase then it is to the United Kingdom that one has to look. Between 1977 and 1991, the United Kingdom Gini coefficient rose by 10 percentage points.”

Among developing countries, China shows a similar trend in rising income inequality. Starting from a relatively low Gini coefficient of household income of 25.7 on a scale of 100 in 1984, China reached a relatively high Gini coefficient of income of 37.8 in 1992. Over a short period of 8 years, the Gini coefficient in China increased 12 percentage points, and the rising trend has been continuing to the present. To illustrate the significance and uniqueness of the Chinese case, note that the Gini coefficient in India remained almost constant for forty years (1951-92) with a mean of 32.6 and a standard deviation of 2.0 (see Li, Squire and Zou, 1998, for more details on the evidence of intertemporal stability in the Gini coefficients for over forty countries).

The Chinese case is even more interesting when we consider its spectacular output growth since the economic reforms initiated in 1978. Over a period of 16 years (1978-1994), the average growth rate in terms of real GDP was 9.86 percent. This positive correlation between 
income growth and inequality immediately throws doubt on the significant negative association between income growth and inequality found in Alesina and Rodrik (1994) and Persson and Tabellini (1994) based on both theory and a cross section of international data. This positive correlation between growth and inequality also contradicts an influential World Bank study The East Asian Miracle (World Bank, 1993), which found economic growth to be associated with low and declining levels of inequality for the eight East Asian countries excluding mainland China. On the other hand, this positive correlation seems to support the age-old Kuznets (1955) inverted U-curve and the more complicated theoretical relationship between economic growth and income inequality in Greenwood and Jovanovic (1990), Banerjee and Newman (1993), Galor and Zeira (1993), Perotti (1993), and Benabou (1996), among many others (see Benabou, 1996, or Atkinson, 1997, for a survey and further developments).

What accounts for the rapid rise in income inequality in China? Recent advances in income distribution theory mentioned above provides plenty of channels. While many of these theoretical models have confronted cross-country data, very few examine individual countries. In this paper, we follow Banerjee and Newman (1993), Galor and Zeira (1993), and Atkinson (1997), and apply their theoretical insights to the case of China. Since 1978 China's experience provides a fertile field for testing the determinants of changes in income inequality explored in many recent theoretical contributions. We broaden the Benerjee-Newman and Galor-Zeira framework, and look at the role played by output growth, increasing exposure to international trade, urbanization, taxation and government spending, inflation, human capital formation, geography, and especially the sectoral structure of the economy (the share of state enterprises) in determining the changes of income inequality. Theoretical considerations of all these factors will be presented in section II. 
Section III provides a brief description of our provincial panel data on urban income distribution and all explanatory variables in our empirical study. We provide detailed regression analysis on the determinants of income inequality in Chinese provinces in sections IV and V. In section VI, we summarize our findings and offer concluding remarks on the direction for further work.

\section{Some Analytical Considerations}

\section{II.1 The Occupational Choice between the State Sector and Private Sector}

In China and other transition economies the obvious choice facing individuals is whether to continue to work in the state sector or find new employment and set up a money-making business in the private sector. Since the reform starting in 1978, the share of state-owned industrial output has continued to decline. The reduction is most dramatic in coastal provinces like Hainan and Guangdong, where state-owned enterprise (SOE) share of industrial output had declined as much as 30 to 40 percentage points. To model this choice and its effect on income distribution, we follow the ideas in Banerjee and Newman (1991, 1993), and Galor and Zeira (1993). In general, the state sector continues to provide a stable and meager income plus various fringe benefits including free or cheap health care, schooling, and housing. These benefits are denoted $w_{s}$. All agents live for two periods as in Galor and Zeira (1993). In the first period, they can either work in the state sector or invest in the private sector. All agents in our model maximize their life-time earning. If agents work in the state sector, they earn $w_{s}$ for both periods. During the first period, since they do not consume, their savings generate a capital income at a safe rate $r$. Therefore, their life-time income, $y_{s}$ is

$$
y_{s}=(1+r)\left(x+w_{s}\right)+w_{s},
$$


where $x$ is the initial endowment for agents. As in Banerjee and Newman (1993), we assume that all agents are risk neutral. The risk-neutral assumption allows us to exclude the role of risk aversion in risk-taking and occupational choices. Therefore agents in the state sector maximize their expected life-time income or expected second-period consumption:

$$
\operatorname{Max} E U\left(y_{s}\right)=E\left(y_{s}\right)=y_{s}=(1+r)\left(x+w_{s}\right)+w_{s},
$$

where $E$ is the expectation operator.

For agents undertaking investment in the private sector, the investment project is indivisible and requires an initial investment of $I$ units of capital ${ }^{2}$. Here we can take $I$ to be a combination of investment in both physical and human capital. If the project succeeds, it generates a random return $\pi I$ where $\pi$ is $\pi_{h}$ or $\pi_{l}$ with probabilities q and 1-q, respectively, with $\pi_{h}>\pi_{l}>0$. Since all agents are assumed to be risk neutral, the agents in the private sector maximize their life-time expected income $y_{p}$ :

$$
E U=E\left(y_{p}\right)=(x-I)(1+r)+I\left[q \pi_{h}+(1-q) \pi_{l}\right]
$$

if the initial endowment $x$ is larger than $I: x>I$.

As in Banerjee-Newman and Galor-Zeira models, the credit market is assumed to be imperfect. In fact, in China only the powerful and the well-connected agents have access to credit markets at reasonable borrowing costs. If agents intend to invest in the private sector by credit financing, the cost is given by:

\footnotetext{
${ }^{2}$ See the similar indivisibilities of investment in Galor and Zeira (1993) for human capital investment and
} Banerjee and Newman (1993) for physical capital investment. Indivisibilities are very essential for history dependence and multiple equilibria in the model. Otherwise, with decreasing returns to scale, it is possible for income distribution across individuals to become more equilized over time, see Stiglitz (1969), Chatterjee (1994), Caselli and Ventura (1996), and Li, Xie, and Zou (1996). 
CEMA Working Paper No. 473

$$
h(b)=(1+R-\delta) b+\frac{\mu}{2} b^{2},
$$

where $b$ denotes the amount borrowed, $R(>r)$ is the official borrowing rate, which is never available to the public, $\delta$ is the power index, and $\mu$ is a positive parameter reflecting convex borrowing costs. For the initial poor with no political power or connections, they have no access to the credit market at the official rate $R$. Actual lending rates in the credit markets depend on the official rate, the power index and a rising marginal cost of borrowing. Those agents choosing to borrow will maximize their expected income:

$$
E U=E\left(y_{b}\right)=(1+r)(x+b-I)+I\left[q \pi_{h}+(1-q) \pi_{l}\right]-(1+R-\delta) b-\frac{\mu}{2} b^{2}
$$

The optimal choice of $b$ is a function of the official lending rate $R$, the power or connection index $\delta$, the deposit rate $\mathrm{r}$, and the rising-cost parameter $\mu$ :

$$
b=b(R, \delta, \mu, r) .
$$

Agents with an initial endowment $x$ larger than $I$ or initially rich agents choose not to work in the state sector if and only if

$$
\left[q \pi_{h}+(1-q) \pi_{l}-(1+r)\right] I>w_{s}(2+r) .
$$

In inequality (7), the left-hand side is the expected excess return on the indivisible investment in the private sector, and the right-hand side is the life-time earning in the state sector. Therefore, if (7) holds, initially rich agents with investment in the private sector will become even richer in the second period compared to the employees in the state sector. In a province with a larger private sector, income distribution is likely to be more unequal compared to a province with a large share of state ownership. 
In this paper, we will call agents with power and connection, and access to credit finance as "powerful". The powerful will invest in the private sector instead of working in the state sector if and only if

$$
I\left[q \pi_{h}+(1-q) \pi_{l}-(1+r)\right]+b(R, \mu, \delta, r)(1+r)-h(b(R, \mu, \delta, r))>w_{s}(2+r)
$$

The left-hand side is the net gain from investment through borrowing in the credit market, and again the right-hand side is the life-time earning in the state sector. Therefore, agents even with poor initial resources but politically powerful are likely to become the new rich in the second period if credit costs are not exceedingly high. Agents with an initial endowment $x$ smaller than $I$ and without access to credit or cannot afford the credit will continue to work in the state sector. All things given, these poor agents in both economic and political terms will likely remain poor in the second period because they are excluded from the credit markets. The driving force for this result is the indivisibility of investment projects, as in Banerjee and Newman (1993) and Galor and Zeira (1993).

The model thus yields a few implications. The initial rich in the urban sector will become richer through their investment in the private sector; the initial poor will remain poor as the employees of the state sector if they lack political clout and access to credit markets; and the powerful, even without sufficient initial resources, may gain as a result of their access to credit and profitable, money-making opportunities.

\section{II.2 The Role of Other Factors in Determining Income Inequality}

Our simple model allows us to consider the effects of various other factors on income distribution. First, aggregate growth can influence both the state sector and the private sector. An increase in the demand for the products manufactured in the state sector can lead to a higher 
wage $w_{s}$ in equation (1) for the employees in the state sector, which may improve income distribution ceteris paribus. Meanwhile, the rising aggregate demand for products in the nonstate sector can lead to a higher probability of success in the private investment project $q$ or a higher average return on the private investment. With rising expected profits from investment as a result of the rise in market demand, the powerful can afford to borrow more and improve their economic lot in life. Thus the initial rich and the powerful may benefit from the increase in market demand disproportionally than the initial poor. If this is the case, income distribution can become even more unequal. For our empirical analysis, we take provincial GDP growth as an approximation for the aggregate change in market demand.

Second, foreign trade and foreign direct investment have played a special role in both the product market and the credit market in China. During the reform period, the government has granted export subsidies and foreign exchange retention to various special economic zones and open cities in different regions in order to promote exports. Their effects on wages and profitability can be favorable to both the state sector and the non-state sector. Trade licenses and quotas seem to benefit the rich and the powerful much more than the poor. The powerful have a direct access to trade licenses and quotas, and the rich can obtain these trade privileges through bribery and numerous other measures. Foreign direct investment and joint ventures can create or reduce the imperfection of the credit or capital market in China. The powerful and the rich are in a better position to collude with foreign investors in granting licenses for foreign direct investment and joint ventures. In this way, the powerful and the rich can benefit disproportionally from the rents generated by foreign direct investment. On the other hand, the flow of foreign capital into China naturally reduces the high borrowing cost in the credit market, and that may increase the possibility even for the poor to set up private businesses as a result of 
lower borrowing cost parameters $R$ and $\mu$ in equations (4) and (5). Therefore, the net effect of foreign trade and foreign direct investment on income distribution is not clear.

Third, geographical location is relevant for income distribution across provinces. Coastal provinces like Guangdong and Fujian have a natural advantage in serving domestic and foreign demand through the sea ports and expanding their product markets to Hong Kong, Taiwan, the Pacific Rim, and Northern America. This partly explains why foreign direct investment and joint ventures have concentrated in coastal provinces in China. Since this concentration can significantly improve the access to the credit market not only for the rich and the powerful, but also for the poor in coastal provinces, geographical advantage may reduce income inequality in coastal provinces relative to inland provinces.

Fourth, large increases in the share of urban population are observed across provinces since 1978. Our model shed light on the effect on urban income distribution of urbanization and migration from the rural sector to the urban sector. If migrants have accumulated a certain amount initial capital through their individual efforts or through the contributions from their rural communities or extended families, and if these funds are sufficient for them to set up private businesses in the urban sector, their migration to cities and towns can increase the number of the middle class or they may even become the new rich. That may even improve urban income distribution. But if migrants are very poor peasants and go to cities and towns to find employment opportunities, they may earn a lower wage in the informal sector than employees in the state sector. As a result, they become the new poor of the urban sector, and urban income distribution can become more unequal. Thus it is not clear how urbanization affects urban inequality. 
Fifth, the importance of income policy in the distribution of personal income has been emphasized by Atkinson (1997). If taxation and public spending intend to remedy income inequality, the government can tax investment income in the private sector and subsidize the workers and the poor in the state sector. Accordingly, income distribution is expected to improve. But if tax revenues are channeled to subsidize credit for the politically powerful, income for the powerful may rise and income inequality may even increase. Furthermore, government spending may worsen income distribution if redistribution and public spending are tilted toward the middle class, the rich, and the powerful instead of the poor in education, health, and social welfare. Thus the net effects of income policy on inequality is ambiguous.

Sixth, inflation can affect the poor more than the rich and the powerful. In reality, the assets of the rich and the powerful are more diversified (stocks, equities, land ownership, private housing, and business ventures), whereas the urban poor and the state-sector employees depend mainly on salary and pension income, which are usually fixed at a nominal term and adjusted only slowly to the inflation rate. Thus, we expect that inflation raises income inequality and reduces the income share of the poor.

\section{Data and the Changes of Income Distribution in China, 1985-95}

Current descriptive studies on inequality in China have mainly relied on per capita income and per capita consumption comparisons across provinces because systemic data on regional income distribution is lacking. Many studies report alarming, ever-growing disparities across provinces in terms of per capita income and consumption (Lyons 1991; Tsui 1991, 1996). Yet there is no provincial-level data on income inequality. We try to fill this gap by employing the published results of average incomes of different percentiles for urban residents in each 
province (World Bank, 1996). This new data set allows us to examine more closely how the poor are doing in each province, how the incomes of the poor and the rich income are determined, and how the income of the poor and economic growth are linked.

It is useful to get to know the data before proceeding to examine the income distribution of Chinese provinces. Based on the urban household surveys, the data we use covers the period of 1985 to 1995 (except 1987 and 1988) on the income distribution of urban residents of each province. For the 1989-95 period, there are 20 average incomes for each 5 percentiles (5 percentile, 10 percentile, and so on). For 1985 and 1986 the data are less perfect: we have the average incomes of the bottom 10 percentile, the next 10 percentile, the next three quintiles, then the top two 10 percentiles. ${ }^{3}$ Based on these data we computed the Gini coefficients, the percentage of income of top quintile in total income (Q5), that of bottom quintile (Q1), and that of the third and fourth quintiles (Q34), and the ratio of the percentage of Q5 over that of Q1 (Q5/Q1).

While the computation of the rest of the measures is straightforward, the computation of the Gini coefficient is more complex. To compute this measure we used an approximation method, which has the virtue of being simple and without imposing parametric assumptions about the Lorenz curve. In general, however, it underestimates the Gini with the assumption of a relative smooth Lorenz curve, and the downward bias decreases with the number of percentile points. When twenty 5-percentiles are used, for instance, the upper bound of underestimation of the Gini is 0.025. When 7 percentiles (as in 1985 and 1986) are used, however, the underestimation bias should be larger. In all our future regressions we correct for this problem by including a dummy variable whose value is 1 for the years of 1985 and 1986 . This dummy

\footnotetext{
3 . In 1985, we also have the average income of the bottom 5 percentile.
} 
variable should capture the underestimation of the Gini, and other systematic biases for quintiles in 1985 and 1986. Since we cannot determine exactly the size of the bias here our descriptive discussion of income distribution shall focus on the 1989 to 1995 period. In later regressions we include 1985 and 1986 dummies to filter out the bias.

Since 1978 urban residents in most provinces have witnessed a worsening income distribution. Between 1989 and 1995 the Gini coefficient increased by 2.4 points (from 21.0 to 23.4). The ratio of $\mathrm{Q} 5$ over $\mathrm{Q} 1$ rose from 2.0 to 2.6. Underlying these figures is an increasing disparity between the rich and the poor: Q5's claim to total income went up from 27 percent to 31.7 percent, and Q1's share dropped from 14.6 percent to 12.5 percent. The middle class (Q34) also slightly suffered with the lapse of time: its share dropped by almost 1 percent from 41 .

Worsening income distribution was by no means evenly shared among the provinces (table 1). Some provinces, such as Guangdong, Guangxi, Hunan, Qinghai, did not change much; Xinjiang, located in the northwest corner of China, even improved its Gini by 1.3 point. Other provinces, in contrast, dramatically raised their Gini: Tianjin (one of the three municipalities) increased its Gini by more than 9.3 points, (inland) Henan by 9.5, (inland) Heilongjiang by 9.2, and (inland) Sichuan by 9 points. To summarize the changes in income distribution by provinces, table 2 presents the trend of the Gini coefficient by province. We found that 19 of the 29 provinces had a positive and statistically significant trend. No province experienced a negative and significant trend in the Gini. More strikingly, Q5 increased significantly in 27 provinces, and Q1 decreased significantly in 24 provinces. The share of the middle class, Q34, dropped significantly in 7 provinces, and increased significantly in 3 provinces. Thus the more fundamental trend behind the worsening of the Gini is the increasing claim of wealth by the rich and the opposite for the poor in almost all provinces. 
While the income distribution worsened, the total pie for the Chinese grew. The average per capita GDP growth rate was 8.8 percent (table 3). The provinces exhibited a large difference in their growth. While the average growth rate was 4.8 percent for (inland) Qinghai, 5 percent for (inland) Heilongjiang, 6.3 percent for (inland) Guizhou, it was 14.2 for (coastal) Guangdong, 13.9 for (coastal) Zhejiang, 12.7 for (coastal) Fujian, and 11.7 for (coastal) Jiangsu. The coefficient of variation for growth rate was also non-trivial: from 0.09 to 0.19 . The correlation between the growth rate and the Gini coefficient is 0.27 .

Accompanying the growth, the share of the volume of import and export to GDP increased dramatically. The highest trade shares, not surprisingly, were seen in Beijing, Fujian, Guangdong, Shanghai, and Tianjin, which are located near the seashore. The largest change in trade share over time also belonged to these trade giants. The dwarfs of trade were mostly inland provinces (the smallest being Guizhou, which saw a moderate increase in trade; Henan, which also had the second worst increase in trade share; Qinghai, which also had quite slow growth in trade share). The correlation between trade share and the Gini coefficient is 0.22.

Table 4 presents the correlation matrix for the variables we shall use. Note a high positive correlation between the Gini and inflation rate. The correlation between the Gini and schooling (as measured by the percentage of population having above secondary schooling) is -0.02 , small in magnitude. Government expenditure (as measured by the share of budgetary expenditure of total GDP) also had negligible correlation with the Gini. In addition, note the strong correlation of GDP growth with both the trade share and urbanization growth, and its negative correlation with the SOE share and that province's distance to the coast by railroad.

\section{The Empirical Specifications and Issues}


Based on discussions in section II, our examination of income inequality involves these variables: (a) the occupational structure, specifically, the share of state-owned enterprises (SOES); (b) macro economic policies, in particular, as an implicit transfer (from the poor to the rich), the inflation rate (INFL), and as an explicit transfer, the share of government budgetary expenditure as a share of GDP (GEXPS); (c) geography as measured by the distance of a province’s capital to the nearest port by railroad (DISTA); (d) the share of residents with more than secondary schooling (SCH); (e) GDP growth rates; (f) the involvement of the provinces in foreign trade, as measured by the ratio of the value of the volume of import and export to GDP (TRADE), and finally, (g) the change of urbanization level of a province, as measured by the growth rate of the share of non-agricultural population in the province (URBANGR). ${ }^{4}$

Note that the variables we use are province-level (not just the urban sector) measures. Ideally one wants to use the urban measures, but unfortunately it is not feasible given the data we have and all the sources we have checked. On the other hand, some variables have less problems. SOE, for instance, does not present a major problem because all SOEs are located in the urban domain. In addition, INFL in urban areas should be quite closely related to provincial inflation rates. Lastly, URBANGR is the ideal measure, because we want to see how urbanization growth itself affected the income distribution within the urban sector. This said, now we estimate the following equation ${ }^{5}$ :

4. We chose not to use the growth of urban population because urban population, by official statistics, consisted of both true urban residents and farmers. Urbanization should therefore be measured as the share of nonagricultural population.

5 . This specification is very close to Edwards (1997) and Li, Squire and Zou (1998) for cross-country study on the determinants of income inequality. The SOE share and geographic location are the added, special features for China. 


$$
\begin{aligned}
& y_{i t}=\beta_{0}+\beta_{1} S O E_{i t}+\beta_{2} I N F L_{i t}+\beta_{3} \text { DISTA }_{i}+\beta_{4} S C H_{i t}+\beta_{5} G D P G R \\
& +\beta_{b} T_{R A D E}+\beta_{7} \text { GEXPS }_{i t}+\beta_{8} U_{R B G R_{i t}}+\phi_{i}+\varepsilon_{i t}
\end{aligned}
$$

where $y_{i t}$ could be GINI, Q5/Q1, Q5, Q1, and Q34. We wish to examine how the explanatory variables affected the inequality (GINI, Q5/Q1), the rich (Q5), the poor (Q1), and the middle class (Q34). $\phi_{i}$ is unobserved province-specific factors that may affect $y_{i t}$. The inclusion of $\phi_{i}$ is justified by the finding that inequality tends to persist over time (Li, Squire and Zou 1997). When $\phi_{i}$ is correlated with the included explanatory variables $\left(\mathrm{X}_{\mathrm{it}}\right)$, the fixed effects (FE) (or the least square dummy variables, LSDV) model is appropriate. When $\phi_{i}$ is not correlated with $\mathrm{X}_{\mathrm{it}}$, a random effects model is more efficient than a FE model. We can test the correlation by the Hausman-Wu test, whose basic idea is that, if $\phi_{i}$ is correlated with $\mathrm{X}_{\mathrm{it}}$, then FE estimates should differ significantly from RE estimates; consequently, if the difference of the two vectors of estimates is large, FE is preferred. In order to see whether the results are robust--since the theory does not tell us what conditioning information set is appropriate for the effects of variables of interests (Levine and Renelt 1992)--we experimented with many different sets of regressors. In particular, we consider SOES, INFL, DISTA, SCH, and GDPGR as the base set of regressors about whose impacts on outcomes we are most concerned. Then we add accumulatively one variables at a time, and all results are reported.

While FE estimates should filter out the time-invariant province-specific factors, we still have to consider the potential correlation of some elements of $X_{i t}$ with $\varepsilon_{i t}$. Among $X_{i t}$ we consider DISTA, INFL, and SCH exogenous: (a) DISTA is a purely natural endowment; (b) SCH measures the percentage of population with more than secondary schooling, surveyed once every five years. This stock of human capital was largely a consequence of past history, unlikely to be correlated with $\varepsilon_{i t}$. (c) INFL is seen as exogenous because the monetary policy was set by 
the central banks, and unlikely to be correlated with the province-specific time-variant $\varepsilon_{i t}$. It is still possible that $\varepsilon_{i t}$ follows an $\operatorname{AR}(1)$ process, and that $\varepsilon_{i t-1}$ affected INFL $L_{i t}$; however, we have experimented with allowing $\varepsilon_{i t}$ to be distributed as $\operatorname{AR}(1)$, and the results remained largely similar to FE estimates. Since our main concern is the correlation of endogenous variables with $\varepsilon_{i t}$-- and we control for provincial dummies--the lagged value of the endogenous variables should be considered predetermined, likely to be uncorrelated with $\varepsilon_{i t}$, and therefore, qualify as instruments. In addition, the share of rural industrial output in total rural output is strongly correlated with GDPGR and TRADE; yet it should not affect $\varepsilon_{i t}$, which measures the contemporaneous shock affecting the province’s urban sector. Thus, it is also a natural instrument.

\section{Results}

Table 5 to table 9 report the empirical results. For each measure of income distribution (GINI, Q5/Q1, Q5, Q1, and Q34), we run OLS, FE, RE, and FE+2SLS model (in which we control for provincial dummies and also use the aforementioned instruments for two-staged least square estimation). The OLS results are not reported because all tests show them to be statistically inferior. In addition, we have experimented with a FE model (by controlling provincial dummies) with the AR(1) error term. The results are very similar to FE estimates; thus, we do not bother the reader with more numbers.

\section{The Gini Coefficient (Table 5)}

For model (1) and model (2) the Hausman-Wu test favors FE and for models (3) and (4) it favors the $\mathrm{RE}$ model. The $\mathrm{R}^{2}$ reported for FE and $\mathrm{RE}$ models are $\mathrm{R}^{2}$ within, computed using FE model 
formulae--it measures the extent the deviation of the Gini from its provincial mean can be explained by by using the explanatory variables. The $\mathrm{R}^{2}$ between (measuring the ability of the model to explain the difference between provincial means) tended to be very small, suggesting that our FE estimates fails to explain the level of the Gini coefficient. Yet, the $\mathrm{R}^{2 \text { s }} \mathrm{s}$ within are quite high, all above 0.69 . Thus the changes of the provincial Gini’s can largely be explained by our measures.

The results for SOES, INFL, and SCH are robust. Provinces with higher SOE share had smaller Gini coefficients. The estimates suggest that an increase of a standard deviation of SOES would be associated with an increase of the Gini by 1.2 to 2.8. Provinces with higher inflation rates had higher Gini's: a standard deviation of INFL was associated with an increase of the Gini by 0.7 to 1.0. The finding supports our earlier discussion. By the preferred FE or 2SLS models, a higher education probably increased the Gini. Before rushing into any judgment, note that SCH did not show large variations across time in our data set, and that it was fixed in every five years; so, for the purpose of accounting for the change of income inequality, SCH is not capable of contributing much. In fact, when we look into a similar measure of the Gini, Q5/Q1, this result no longer holds.

Growth (GDPGR) increased the Gini and is quite significant in all specifications except in the 2SLS model that controls for provincial dummies; in the latter model the sign remains positive, but becomes insignificant and smaller when we do not control for URBANGR. When URBANGR is controlled for in model (4), however, GDPGR become marginally significant. ${ }^{6}$ Similarly, the share of foreign trade in GDP (TRADE) was significant in FE and RE

\footnotetext{
$6 \quad$ This finding is consistent with the positive association between inequality and growth in a cross-country study by Edwards (1997).
} 
specifications for all models. The use of 2SLS does not alter its sign, but it becomes insignificant. Whereas government expenditure is supposed to reduce income inequality, the opposite is found: models (3) and (4) consistently suggest that it increased inequality; a standard deviation increase of GEXPS was associated with an increase of the Gini by 0.9 point (RE) to 1.2 point (2SLS). Finally, increasing urbanization (URBANGR) might have reduced income inequality; the large standard errors for estimates, however, urge caution.

In examining Q5/Q1 (table 6), we find similar results compared to the case of the Gini. This is hardly surprising. After all, they are both good summary statistics of inequality. A comforting discovery, though, is that GDPGR remains quite significant in the models of 2SLS with FE. Later, we shall add more support for this finding by examining how GDPGR improved Q5 and reduced Q1. Another finding is that the coefficient of schooling no longer approaches significance; and when we use 2SLS, the sign reverses. Lastly, GEXPS now has larger standard deviations, although the qualitative results remain intact.

\section{Q5 (Table 7)}

From model (1) to model (4), FE specification won the statistical contests convincingly, as witnessed by the small P-values of the Hausman-Wu test. Moreover, the use of instruments in general does not fundamentally change any result. The $\mathrm{R}^{2 \text { s }} \mathrm{s}$ within for FE are not as high as in the case of the Gini.

The market from 1985 to 1995 certainly benefited the rich. Q5, for instance, increased significantly with INFL, whose increase of one standard deviation was associated with about 0.5 point increase of Q5. Furthermore, Q5 moved shoulder to shoulder with GDPGR, whose increase by one standard deviation increased Q5 by 0.6 to 0.7 according to point estimates. 
TRADE has ambiguous signs when we compare FE (and RE) with 2SLS and with provincial dummies. When we increase the conditioning information set from model (2) to model (4), it becomes increasingly less significant. The use of instruments made it flip signs, but the large standard error precludes any strong assertion here.

The restraining force for the increase of Q5 seems to come mainly from the state. First, a large SOES was associated with lower Q5, a finding consistent with our assumption in the model. Moreover, a standard deviation increase of GEXPS was associated with 0.8 point decrease of Q5. Unrelated to the state, the direction of the effects of URBANGR on Q5 is not clear: the large standard deviations for FE and 2SLS estimates warrants caution.

Provinces that are far away from the coast have a larger Q5; this is consistent with our conjecture that inland capital markets are more imperfect. Another finding is that, in FE models, SCH seems to raise Q5; yet once instruments are used, its sign flipped. This finding suggests that higher Q5 for provinces with higher SCH reflected probably just the positive correlation of SCH with the error term in FE estimation.

\section{Q1 (Table 8)}

FE specifications still dominate RE ones, except in model (3). But the inclusion of instruments seems to matter. The $\mathrm{R}^{2}$ within are similar to $\mathrm{Q} 1$ : whereas a bit less than half of the variance of the changes of Q1 can be explained by our variables, still more cannot be explained by our model.

The most noticeable finding is that the forces that increased Q5 also reduced Q1, thus the poor came out of this period as the loser. INFL certainly had reduced the income share of the poor. When INFL increased by one standard deviation, Q1 would decline by around 0.4 
percentage point. GDPGR, another force that helped the rich, harmed the poor in terms of relative share of income. When GDPGR increased by one standard deviation, Q1 dropped by 0.4 point (FE), and 2SLS implies an even larger figure, especially when the conditioning information set is larger. TRADE, while helped the rich, again hurt the poor. The sign flip with the use of instruments does not suggest a strong effects of TRADE on the poor. Finally, the poor farther from the seashore claimed a smaller share of total income, an observation consistent with the role of imperfect capital markets in reducing the poor's income in inland areas.

The state did not help the poor. The reduction of SOES reduced Q1. One standard deviation decrease of SOES would at least reduce Q1 by a whopping 7 points, even by more than 10 points when a larger conditioning information set is used. In addition, GEXPS did not significantly help the poor. The consistently negative signs with large standard errors may even suggest the opposite. Finally, URBANGR did not give a consistent message: it was insignificant in FE and RE estimation, and approached significance in 2SLS.

\section{Q34 (Table 9)}

Although our variables are least useful in predicting the fortune of middle class, the within $\mathrm{R}^{2}$ are the largest when compared to Q1 and Q5. This is hardly surprising. Q34 hardly changed on average over the period (at least for 1989-95). For most models, the Hausman-Wu tests do not favor FE or RE consistently. Not a single variable significantly affected Q34 consistently. We have some weak evidence that GDPGR reduced Q34, but the standard errors of estimates are large.

\section{Conclusion}


Examining the experiences of 29 provinces over 11 years, we have focused on how the change of income distribution (and the income share of the rich, the poor, and the middle class) had been affected by the changing structure of economy (higher growth rates, increasing exposure to foreign trade), the role of the state (the reduction of SOE sector, and more decentralized fiscal expenditure), and increasing urbanization. We have found that inequality and Q5 increased with, and Q1 decreased with, the reduction of SOE share, higher inflation and growth rates, and (less significantly) the increasing extent of foreign trade. We have also found some evidence for Director’s Law (Stigler 1970): income redistribution tends to shift resources from the rich and the poor to the middle class, as witnessed by the positive sign on Q34, but generally negative signs of Q5 and Q1. Intriguingly, provinces farther from the coast had larger inequality, an observation probably reflecting the consequences of greater imperfection of capital market. Schooling and increasing urbanization did not play a significant role in the increasing income inequality during this period.

The findings of this paper answer some questions, but elicits more questions. Is it inevitable that growth and openness will increase income inequality? Will the poor necessarily be the loser of the growth gains? Under what circumstances do the above scenarios arise? If the scenario is true, what can governments do to reduce the suffering of the poor during growth and global economic integration processes? In addition, given the nature of this data, and the short time-span we have, some questions evade answer. What determines, for instance, the level differences across different provinces? Further research is needed to answer these questions. 
CEMA Working Paper No. 473

\section{Data Appendix}

Our empirical estimations are based on annual data for 29 provinces. Data sources are all official publications in China. Although over 100 volumes of statistical publications are involved, major data sources include China Statistical Yearbook and provincial statistical yearbooks for various years. Variables used for estimations are listed below with their data sources. Names of provincial areas included in our estimations are also listed.

GDPGR $=$ the real growth rate of provincial GDP, measured at constant price level. Source: For 1985-1995: China Statistical Yearbook (Zhongguo Tongji Nianjian) various issues.

TRADE $=$ the degree of openness of a provincial economy, measured by the share of total volume of foreign trade (exports and imports) in provincial income.

Source: Almanac of China's Foreign Economic Relations and Trade (Zhongguo

Duiwai Jingji Maoyi Nianjian), various issues in 1984-1994/95.

INFL = the inflation rate, measured by the overall social retail price index in each province.

Source: China Statistical Yearbook (Zhongguo Tongji Nianjian), various issues.

GEXPS = total provincial public spending over provincial GDP.

Source: For provincial population and government spending: various volumes of provincial statistical yearbooks.

URBANGR= the growth rate of the share of urban population of total provincial population:

Source: Various volumes of provincial statistical yearbooks.

$\mathrm{SCH}=$ share of population with more than secondary schooling in each province. 
CEMA Working Paper No. 473

Source: Various volumes of provincial statistical yearbooks.

SOE = share of SOEs output in provincial GDP.

Source: Various volumes of provincial statistical yearbooks.

\section{List of provincial areas:}

Beijing, Tianjin, Hebei, Shanxi, Neimenggu (Inner Mongolia), Liaoning, Jilin, Heilongjiang, Shanghai, Jiangsu, Zhejiang, Anhui, Fujian, Jiangxi, Shandong, Henan, Hubei, Hunan, Guangdong, Guangxi, Sichuan, Guizhou, Yunnan, Shaanxi, Gansu, Qinghai, Ningxia, and Xinjiang. 


\section{REFERENCES}

Alesina, A. and D. Rodrik (1994). Distributive politics and economic growth. Quarterly Journal of Economics, 109, 465-490.

Atkinson, T. (1997). Bring income distribution in from the cold. Economic Journal, 107, 297321.

Banerjee, A. and A. Newman (1993). Occupational choice and the process of development. Journal of Political Economy, 101, 274-298.

Benabou, R. (1996). Inequality and growth. In NBER Macroeconomics Annual 1996. MIT Press.

Caselli, F. and J. Ventura (1996). A representative consumer theory of distribution. Working paper, Harvard University and MIT .

Chatterjee, S. (1994). Transitional dynamics and the distribution of wealth in a neoclassical growth model. Journal of Public Economics, 54, 97-119.

Edwards, S. (1997). Trade policy, growth, and income distribution. American Economic Review, 82, 205-210.

Galor, O. and J. Zeira (1993). Income distribution and macroeconomics. Review of Economic Studies, 60, 35-52.

Greenwood, J. and B. Jovanovic (1990). Financial development, growth, and the distribution of income. Journal of Political Economy, 98, 1076-1107.

Kuznets, S. (1955). Economic growth and income inequality. American Economic Review, 45, 128.

Levine, R. and D. Renelt (1992). A sensitivity analysis of cross-country growth regressions. American Economic Review, 82, 942-963. 
Li, H., L. Squire and H. Zou (1998). Explaining international and intertemporal variations in income inequality. Economic Journal, 108, 26-43.

Li, H., D. Xie, and H. Zou (1996). Dynamic of Income Distribution. Forthcoming in Canadian Journal of Economics.

Li, H., and H. Zou (1998). Income inequality is not harmful for growth: Theory and evidence. Review of Development Economics, 2, 318-334.

Lyons, T. (1991). Interprovincial disparities in China: Output and consumption. Economic Development and Cultural Change, 39, 471-506.

Perotti, R. (1993). Political equilibrium, income distribution, and growth. Review of Economic Studies, 60, 755-776.

Persson, T. and G. Tabellini (1994). Is inequality harmful for growth? Theory and evidence. American Economic Review, 84, 600-621.

Tsui, K. (1991). China’s regional inequality, 1952-1985. Journal of Comparative Economics, 15, $1-21$.

Tsui, K. (1996). Economic reform and interprovincial inequalities in China. Journal of Development Economics, 50, 353-368.

Stigler, George (1970). Director's Law of Public Income Redistribution, Journal of Law and Economics, 13, 1-10.

Stiglitz, J. (1968). Distribution of income and wealth among individuals. Econometrica 37, 382397.

World Bank, (1993). The East Asian Miracle. New York: Oxford University Press.

World Bank, (1996). A Survey on Urban Household Income in China. 
Table 1. Some Statistics of Used Variables: by Province for the Period of 1985 to 1995

\begin{tabular}{|c|c|c|c|c|c|c|c|c|c|c|c|c|c|c|c|c|c|c|c|c|}
\hline & \multicolumn{5}{|c|}{ Gini } & \multicolumn{5}{|c|}{ The real growth rate of } & \multicolumn{5}{|c|}{ The inflation rate } & \multicolumn{5}{|c|}{$\%$ SOE output in provincial GDP } \\
\hline & Mean & $N$ & $x(T)-x(0)$ & $N$ & C.V. & Mean & $N$ & $x(T)-x(0)$ & $N$ & C.V. & Mean & $N$ & $x(T)-x(0)$ & $N$ & C.V. & Mean & $N$ & $x(T)-x(0)$ & $N$ & C.V. \\
\hline Anhui & 19.69 & 11 & 4.76 & 8 & 0.11 & 10.68 & 24 & 1.47 & 19 & 0.88 & 10.2 & 5 & 6.3 & 15 & 0.67 & 49.1 & 7 & -32.84 & 7 & 0.31 \\
\hline Beijing & 17.89 & 2 & 4.27 & 7 & 0.12 & 7.95 & 14 & -0.68 & 17 & 0.67 & 12.46 & 28 & -6 & 1 & 0.46 & 59.26 & 16 & -17.31 & 20 & 0.14 \\
\hline Fujian & 22.56 & 25 & 6.56 & 17 & 0.14 & 12.72 & 27 & -4.61 & 9 & 0.59 & 10.4 & 8 & 3.8 & 8 & 0.75 & 38.41 & 4 & -38.81 & 3 & 0.33 \\
\hline Gansu & 20.3 & 13 & 5.7 & 12 & 0.13 & 8.47 & 16 & -5.21 & 7 & 0.4 & 10.74 & 15 & 8 & 19 & 0.62 & 77.08 & 28 & -21.44 & 15 & 0.09 \\
\hline Guandong & 24.89 & 28 & 3.44 & 2 & 0.12 & 14.22 & 29 & -9.61 & 3 & 0.37 & 10.01 & 4 & -2 & 4 & 0.88 & 35.51 & 3 & -34.56 & 6 & 0.33 \\
\hline Guanxi & 19.96 & 12 & 3.47 & 3 & 0.11 & 10.43 & 23 & 1.72 & 20 & 0.57 & 11.61 & 25 & 5.2 & 13 & 0.77 & 62.95 & 18 & -35.57 & 5 & 0.22 \\
\hline Guizou & 21.45 & 18 & 8.65 & 22 & 0.14 & 6.27 & 3 & 4.49 & 24 & 0.44 & 10.44 & 9 & 9.5 & 23 & 0.65 & 75.3 & 25 & -12.43 & 24 & 0.07 \\
\hline Hainan & 27.89 & 29 & n.a. & n.a. & 0.17 & 10.26 & 22 & n.a. & n.a. & 0.67 & 12.53 & 29 & -1.5 & 5 & 0.77 & 65.93 & 19 & -39.41 & 1 & 0.21 \\
\hline Hebei & 18.12 & 3 & 6.33 & 16 & 0.17 & 9.14 & 17 & 2.04 & 22 & 0.62 & 9.67 & 3 & 8 & 19 & 0.77 & 46.22 & 6 & -22.64 & 14 & 0.19 \\
\hline Heilongjiang & 21.72 & 21 & 9.16 & 24 & 0.15 & 5 & 2 & 9.3 & 26 & 0.69 & 11.23 & 21 & 2.6 & 7 & 0.46 & 76.57 & 27 & -13.12 & 23 & 0.07 \\
\hline Henan & 22.16 & 23 & 9.45 & 26 & 0.19 & 9.15 & 18 & 4.53 & 25 & 0.63 & 8.66 & 1 & 10 & 24 & 0.87 & 49.58 & 8 & -32.28 & 8 & 0.22 \\
\hline Hubei & 18.57 & 7 & 5.69 & 10 & 0.16 & 7.72 & 11 & -3.46 & 12 & 0.68 & 11.04 & 19 & 9.1 & 22 & 0.69 & 57.66 & 14 & -29.4 & 9 & 0.17 \\
\hline Hunan & 22.02 & 22 & 3.71 & 4 & 0.11 & 7.64 & 9 & -4.35 & 10 & 0.48 & 11.43 & 23 & 4.4 & 10 & 0.7 & 57.04 & 13 & -25.65 & 11 & 0.16 \\
\hline Jiangsu & 19.02 & 10 & 6.86 & 18 & 0.17 & 11.74 & 26 & -10.5 & 2 & 0.75 & 10.94 & 17 & 5.1 & 12 & 0.66 & 29.85 & 2 & -19.31 & 17 & 0.24 \\
\hline Jiangxi & 20.64 & 14 & 5.69 & 11 & 0.14 & 9.43 & 20 & -3.53 & 11 & 0.51 & 10.46 & 10 & 7.6 & 18 & 0.76 & 58.45 & 15 & -17.76 & 18 & 0.18 \\
\hline Jilin & 21.38 & 17 & 6.03 & 15 & 0.18 & 6.3 & 4 & 3.68 & 23 & 0.96 & 10.39 & 7 & 4.5 & 11 & 0.54 & 67.73 & 21 & -9.85 & 27 & 0.06 \\
\hline Liaoning & 18.89 & 9 & 7.04 & 19 & 0.15 & 7.23 & 8 & -6.13 & 6 & 0.66 & 10.59 & 12 & 4 & 9 & 0.6 & 56.28 & 12 & -23.74 & 13 & 0.15 \\
\hline Inner & 22.23 & 24 & 5.72 & 13 & 0.12 & 7.89 & 12 & -2.22 & 14 & 0.45 & 10.24 & 6 & 8.3 & 20 & 0.59 & 73.45 & 22 & -15.3 & 21 & 0.08 \\
\hline
\end{tabular}




\section{CEMA Working Paper No. 473}

\begin{tabular}{|c|c|c|c|c|c|c|c|c|c|c|c|c|c|c|c|c|c|c|c|c|}
\hline ongolia & & & & & & & & & & & & & & & & & & & & \\
\hline Ningxia & 21.59 & 19 & 3.93 & 5 & 0.2 & 7.93 & 13 & -0.86 & 16 & 0.61 & 10.67 & 14 & 7.5 & 17 & 0.56 & 76 & 26 & -10.64 & 25 & 0.05 \\
\hline Qinghai & 21.19 & 16 & 4.09 & 6 & 0.09 & 4.82 & 1 & n.a. & n.a. & 0.72 & 11.52 & 24 & 5.6 & 14 & 0.56 & 82.51 & 30 & 4.44 & 29 & 0.03 \\
\hline Shaanxi & 21.72 & 20 & n.a. & n.a. & 0.17 & 6.92 & 7 & -12.57 & 1 & 0.66 & 11.34 & 22 & 10.5 & 27 & 0.69 & 66.43 & 20 & -14.45 & 22 & 0.08 \\
\hline Shandong & 18.5 & 5 & 5.91 & 14 & 0.14 & 11.51 & 25 & 1.84 & 21 & 0.6 & 9.56 & 2 & 7.1 & 16 & 0.67 & 39.87 & 5 & -23.86 & 12 & 0.32 \\
\hline Shanghai & 17.31 & 1 & 8.26 & 21 & 0.19 & 8.39 & 15 & -2.85 & 13 & 0.59 & 12.42 & 27 & -3.4 & 2 & 0.4 & 60.08 & 17 & -37.98 & 4 & 0.23 \\
\hline Shanxi & 23.15 & 26 & n.a. & n.a. & 0.16 & 6.73 & 6 & 11.28 & 27 & 0.69 & 10.51 & 11 & 8 & 19 & 0.67 & 55.24 & 10 & -17.44 & 19 & 0.13 \\
\hline Sichuan & 20.92 & 15 & 8.95 & 23 & 0.18 & 9.31 & 19 & -4.89 & 8 & 0.64 & 10.62 & 13 & 10.2 & 26 & 0.74 & 56.11 & 11 & -29.29 & 10 & 0.21 \\
\hline Tianjin & 18.82 & 8 & 9.33 & 25 & 0.18 & 6.63 & 5 & 0.56 & 18 & 0.7 & 10.76 & 16 & -3.3 & 3 & 0.4 & 53.05 & 9 & -39.04 & 2 & 0.26 \\
\hline Xinjiang & 23.45 & 27 & -1.28 & 1 & 0.12 & 9.59 & 21 & -7.48 & 5 & 0.42 & 11.86 & 26 & 8.6 & 21 & 0.57 & 78.76 & 29 & -10.32 & 26 & 0.04 \\
\hline Yunnan & 18.52 & 6 & 5.49 & 9 & 0.13 & 7.69 & 10 & -1.63 & 15 & 0.41 & 10.98 & 18 & 10.1 & 25 & 0.64 & 74.61 & 23 & -8.5 & 28 & 0.04 \\
\hline Zhejiang & 18.44 & 4 & 7.93 & 20 & 0.16 & 13.89 & 28 & -8.31 & 4 & 0.61 & 11.21 & 20 & -0.5 & 6 & 0.63 & 25.53 & 1 & -21.43 & 16 & 0.29 \\
\hline
\end{tabular}


Table 1. Some Statistics of Used Variables: by Province for the Period of 1985 to 1995 (Continue)

\begin{tabular}{|c|c|c|c|c|c|c|c|c|c|c|c|c|c|c|c|c|c|c|}
\hline & \multicolumn{5}{|c|}{$\mathrm{SCH}$} & \multicolumn{5}{|c|}{ TRADE } & \multicolumn{3}{|c|}{ GEXPS } & \multicolumn{5}{|c|}{ URBANGR } \\
\hline & mean & rank & $x(T)-x(0)$ & rank & C.V. & mean & rank & $x(T)-x(0)$ & rank & C.V. & mean & ank & C.V. & mean & rank & $x(T)-x(0)$ & rank & $c V$ \\
\hline Anhui & 30.14 & 8 & 9.74 & 19 & 0.13 & 6.68 & 6 & 4.3 & 6 & 0.28 & 9.99 & 5 & 0.24 & 0.48 & 12 & -0.63 & 6 & 0.8 \\
\hline Beijing & 64.57 & 30 & 10.17 & 21 & 0.09 & 62.73 & 29 & 210.47 & 30 & 1.49 & 11.88 & 13 & 0.18 & 0.77 & 25 & 0.01 & 23 & 0.84 \\
\hline Fujian & 26.00 & 5 & 7.4 & 10 & 0.11 & 39.41 & 27 & 38.45 & 25 & 0.46 & 13.64 & 17 & 0.22 & 0.48 & 11 & -0.21 & 17 & 1.57 \\
\hline Gansu & 28.12 & 6 & 6.95 & 5 & 0.12 & 5.88 & 4 & 6.64 & 14 & 0.46 & 18.87 & 24 & 0.09 & 0.41 & 6 & -0.12 & 18 & 0.9 \\
\hline Guandong & 34.52 & 13 & 10.27 & 22 & 0.12 & 83.03 & 30 & 132.27 & 29 & 0.7 & 10.62 & 9 & 0.1 & 0.89 & 29 & -0.95 & 4 & 0.78 \\
\hline Guanxi & 30.18 & 9 & 8.41 & 14 & 0.14 & 12.96 & 18 & 7.49 & 18 & 0.34 & 15.4 & 20 & 0.2 & 0.49 & 14 & -0.03 & 20 & 0.86 \\
\hline Guizou & 19.98 & 3 & 7.39 & 9 & 0.12 & 4.79 & 1 & 7.17 & 17 & 0.49 & 18.55 & 23 & 0.12 & 0.39 & 4 & 0.06 & 24 & 1.64 \\
\hline Hainan & 40.28 & 22 & n.a. & n.a. & 0.01 & 34.09 & 25 & 48.32 & 27 & 0.69 & 15.04 & 19 & 0.26 & 0.75 & 24 & -0.47 & 8 & 0.92 \\
\hline Hebei & 38.44 & 18 & 7.03 & 6 & 0.12 & 11.31 & 17 & 0.88 & 2 & 0.28 & 10.48 & 8 & 0.23 & 0.34 & 3 & 0.17 & 28 & 1.04 \\
\hline Heilong & 45.54 & 25 & 9.59 & 17 & 0.1 & 10.92 & 16 & 5.34 & 10 & 0.35 & 13.25 & 16 & 0.18 & 0.64 & 22 & -0.03 & 21 & 0.82 \\
\hline Henan & 39.63 & 20 & 10.37 & 23 & 0.15 & 5.51 & 2 & 3.24 & 3 & 0.28 & 10.39 & 6 & 0.17 & 0.47 & 10 & -0.24 & 16 & 0.72 \\
\hline Hubei & 37.23 & 17 & 6.08 & 1 & 0.11 & 8.85 & 12 & 6.72 & 16 & 0.3 & 10.47 & 7 & 0.17 & 0.68 & 23 & -1.87 & 1 & 1.16 \\
\hline Hunan & 35.05 & 14 & 8.5 & 15 & 0.13 & 8.12 & 11 & 3.29 & 4 & 0.37 & 11.27 & 10 & 0.11 & 0.48 & 13 & -0.32 & 14 & 1.03 \\
\hline Jiangsu & 41.17 & 23 & 9.41 & 16 & 0.09 & 16.12 & 19 & 17.97 & 23 & 0.4 & 7.18 & 1 & 0.13 & 1 & 30 & -0.07 & 19 & 1.09 \\
\hline Jiangxi & 29.92 & 7 & 9.69 & 18 & 0.18 & 7.71 & 8 & 4.61 & 7 & 0.27 & 12.7 & 14 & 0.16 & 0.6 & 20 & -0.29 & 15 & 1.55 \\
\hline Jilin & 46.50 & 26 & 12.04 & 28 & 0.12 & 16.5 & 20 & 10.87 & 20 & 0.39 & 17.23 & 21 & 0.2 & 0.78 & 26 & -0.65 & 5 & 0.93 \\
\hline Liaoning & 48.62 & 27 & 6.4 & 2 & 0.07 & 30.68 & 23 & 6.68 & 15 & 0.18 & 11.8 & 12 & 0.15 & 0.55 & 16 & -0.53 & 7 & 1.05 \\
\hline Neimeng & 39.97 & 21 & 7.69 & 11 & 0.07 & 9.21 & 14 & 6.15 & 13 & 0.4 & 21 & 25 & 0.21 & 0.56 & 18 & -0.41 & 10 & 0.86 \\
\hline Ningxia & 33.72 & 11 & 11.89 & 27 & 0.16 & 8.07 & 9 & 5.22 & 9 & 0.26 & 24.92 & 27 & 0.29 & 0.58 & 19 & -0.37 & 13 & 0.69 \\
\hline
\end{tabular}




\section{CEMA Working Paper No. 473}

\begin{tabular}{|c|c|c|c|c|c|c|c|c|c|c|c|c|c|c|c|c|c|c|}
\hline Qinghai & 25.76 & 4 & 11.27 & 26 & 0.19 & 5.86 & 3 & 4.71 & 8 & 0.35 & 25.13 & 28 & 0.18 & 0.63 & 21 & -1.23 & 2 & 1.79 \\
\hline Shaanxi & 39.34 & 19 & 7.32 & 8 & 0.1 & 9.12 & 13 & 11.5 & 22 & 0.52 & n.a. & n.a. & n.a. & 0.52 & 15 & -0.39 & 11 & 1.22 \\
\hline Shandong & 35.53 & 15 & 10.77 & 24 & 0.1 & 16.5 & 21 & 8.54 & 19 & 0.22 & 8.12 & 2 & 0.18 & 0.8 & 27 & -0.39 & 12 & 0.9 \\
\hline Shanghai & 61.36 & 29 & 9.84 & 20 & 0.06 & 51.99 & 28 & 49.69 & 28 & 0.33 & 9.84 & 4 & 0.13 & 0.83 & 28 & 0.15 & 27 & 0.81 \\
\hline Shanxi & 43.47 & 24 & 11.09 & 25 & 0.11 & 7.08 & 7 & 5.94 & 12 & 0.26 & 13.99 & 18 & 0.19 & 0.55 & 17 & 0.13 & 26 & 1.12 \\
\hline Sichuan & 30.77 & 10 & 8.14 & 13 & 0.13 & 6.5 & 5 & 5.58 & 11 & 0.37 & 11.62 & 11 & 0.15 & 0.4 & 5 & -0.43 & 9 & 1.09 \\
\hline Tianjin & 52.63 & 28 & 7.88 & 12 & 0.06 & 38.92 & 26 & 47.89 & 26 & 0.45 & 13.09 & 15 & 0.21 & 0.45 & 8 & 0.26 & 29 & 1.49 \\
\hline Xinjiang & 33.97 & 12 & 6.75 & 4 & 0.08 & 9.40 & 15 & 3.94 & 5 & 0.18 & 18.49 & 22 & 0.33 & 0.41 & 7 & 0.00 & 22 & 1.35 \\
\hline Yunnan & 19.73 & 2 & 6.68 & 3 & 0.13 & 8.08 & 10 & 11.09 & 21 & 0.48 & 24.79 & 26 & 0.12 & 0.46 & 9 & 0.06 & 25 & 1.39 \\
\hline Zhejiang & 36.64 & 16 & 7.31 & 7 & 0.1 & 17.77 & 22 & 19.18 & 24 & 0.42 & 8.53 & 3 & 0.18 & 0.32 & 2 & -1.03 & 3 & 1.64 \\
\hline
\end{tabular}

Note. Source of data: various volumes of provincial statistical yearbooks. 
CEMA Working Paper No. 473

Table 2. Trend of Inequality Measures over Time (1985-95)

\begin{tabular}{|c|c|c|c|c|c|c|c|c|c|c|}
\hline \multirow[b]{2}{*}{ year } & \multicolumn{2}{|c|}{$\underline{\text { GINI }}$} & \multicolumn{2}{|c|}{ Q5/Q1 } & \multicolumn{2}{|c|}{$\underline{\text { Q5 }}$} & \multicolumn{2}{|c|}{$\underline{\text { Q1 }}$} & \multicolumn{2}{|c|}{ Q34 } \\
\hline & Mean & S.D. & Mean & S.D. & Mean & S.D. & Mean & S.D. & Mean & S.D. \\
\hline 85 & 17.13 & 2.58 & 2.45 & 0.39 & 30.05 & 1.76 & 12.39 & 0.98 & 35.17 & 0.98 \\
\hline 86 & 16.43 & 2.11 & 2.38 & 0.36 & 29.57 & 1.21 & 12.59 & 1.06 & 35.54 & 0.55 \\
\hline 89 & 21.02 & 3.80 & 1.99 & 0.86 & 27.08 & 2.25 & 14.59 & 2.55 & 40.96 & 1.33 \\
\hline 90 & 20.25 & 2.60 & 1.84 & 0.27 & 27.01 & 1.94 & 14.85 & 1.25 & 40.74 & 0.98 \\
\hline 91 & 19.93 & 2.12 & 1.89 & 0.30 & 27.71 & 1.94 & 14.91 & 1.58 & 40.42 & 1.02 \\
\hline 92 & 20.81 & 2.57 & 2.10 & 0.33 & 28.80 & 2.02 & 13.89 & 1.32 & 40.55 & 0.80 \\
\hline 93 & 22.69 & 2.90 & 2.41 & 0.42 & 30.73 & 2.30 & 13.02 & 1.82 & 40.30 & 1.19 \\
\hline 94 & 24.63 & 2.88 & 2.75 & 0.55 & 32.05 & 2.69 & 11.93 & 1.53 & 40.63 & 1.20 \\
\hline 95 & 23.42 & 2.57 & 2.60 & 0.50 & 31.73 & 2.62 & 12.46 & 1.46 & 40.14 & 1.30 \\
\hline
\end{tabular}

Note. These income inequality measures are based on the authors' calculation based on the published accounts of the average incomes of urban residents for various percentiles. No data are provided for 1987 and 1988 because we do not have sources for these two years.

Table 3. Descriptive Statistics of Used Variables

\begin{tabular}{|c|c|c|c|c|c|c|c|c|c|c|c|}
\hline Variable & Obs & Mean & $\begin{array}{l}\text { Std. } \\
\text { Dev. }\end{array}$ & Min & $\operatorname{Max}$ & Variable & Obs & Mean & $\begin{array}{l}\text { Std. } \\
\text { Dev. }\end{array}$ & Min & $\operatorname{Max}$ \\
\hline$\overline{\text { GINI }}$ & 252 & 20.73 & 3.69 & 12.98 & 34.17 & INFL & 261 & 10.84 & 6.72 & -4.40 & 26.8 \\
\hline Q1 & 247 & 13.41 & 1.90 & 5.05 & 19.49 & $\mathrm{SCH}$ & 259 & 36.62 & 12.10 & $1.53^{\mathrm{a}}$ & 68.21 \\
\hline Q5 & 247 & 29.41 & 2.77 & 21.4 & 40.36 & DISTA & 261 & 0.79 & 0.77 & 0.00 & 3.65 \\
\hline Q5/Q1 & 247 & 2.27 & 0.56 & 1.10 & 5.94 & TRADE & 261 & 19.10 & 28.17 & 1.63 & 232.70 \\
\hline Q34 & 247 & 39.41 & 2.40 & 32.25 & 45.57 & GEXPS & 224 & 14.22 & 5.77 & 5.65 & 35.77 \\
\hline
\end{tabular}


CEMA Working Paper No. 473

\begin{tabular}{|c|c|c|c|c|c|c|c|c|c|c|}
\hline GDPGR & 259 & 8.83 & 5.76 & -5.72 & 26.16 & $\begin{array}{l}\text { URBAN } \\
\text { GR }\end{array}$ & 261 & 0.58 & 0.64 & -0.60 \\
\hline SOES & 261 & 58.78 & 17.46 & 14.06 & 87.82 & & & & & \\
\hline
\end{tabular}

a. This low figure is attributed to Tibet. These income inequality measures are based on the authors' calculation based on the published accounts of the average incomes of urban residents for various percentiles.

Table 4. The Correlation Matrix of Used Variables

\begin{tabular}{|c|c|c|c|c|c|c|c|c|c|c|c|c|}
\hline & GINI & Q1 & Q5 & Q5/Q1 & Q34 & GDPGR & SOES & $I N F L$ & $\mathrm{SCH}$ & DISTA & TRADE & GEXPS \\
\hline GINI & 1 & & & & & & & & & & & \\
\hline Q1 & -0.43 & 1 & & & & & & & & & & \\
\hline Q5 & 0.58 & -0.81 & 1 & & & & & & & & & \\
\hline Q5/Q1 & $0.57^{\mathrm{a}}$ & -0.94 & 0.84 & 1 & & & & & & & & \\
\hline Q34 & 0.46 & 0.18 & -0.25 & -0.15 & 1 & & & & & & & \\
\hline GDPGR & 0.27 & -0.36 & 0.43 & 0.36 & -0.06 & 1 & & & & & & \\
\hline SOES & -0.18 & 0.14 & -0.15 & -0.12 & -0.31 & -0.43 & 1.00 & & & & & \\
\hline INFL & 0.40 & -0.23 & 0.31 & 0.30 & 0.19 & 0.25 & -0.27 & 1 & & & & \\
\hline $\mathrm{SCH}$ & -0.00 & 0.22 & -0.23 & -.10 & 0.35 & -0.07 & -0.21 & 0.11 & 1 & & & \\
\hline DISTA & 0.17 & -0.04 & 0.05 & 0.08 & -0.06 & -0.14 & 0.54 & -0.01 & -0.37 & 1 & & \\
\hline TRADE & 0.22 & -0.05 & 0.10 & 0.08 & 0.17 & 0.28 & -0.36 & 0.15 & 0.40 & -0.35 & 1.00 & \\
\hline GEXPS & -0.03 & 0.03 & -0.06 & 0.02 & -0.29 & -0.30 & 0.75 & -0.22 & -0.42 & 0.50 & -0.26 & 1.00 \\
\hline URBANG & 0.15 & -0.19 & 0.28 & 0.21 & -0.05 & 0.39 & -0.20 & 0.31 & 0.11 & -0.14 & 0.12 & -0.17 \\
\hline $\mathrm{R}$ & & & & & & & & & & & & \\
\hline
\end{tabular}

Note. See the data appendix for definition of varables.

a. This correlation is low because we pooled 1985-86 with the data in 1989-95. Recall that we had different number of observations for these two periods, and because of that, GINI is underestimated more in the first period than the second. Not surprisingly, this correlation becomes 0.82 when we only used 1989-95, and it turns to 0.98 when we use only 1985-86. 
Table 5. Determinants of the Gini coefficients (Dependent Variable=Gini Coefficient)

\begin{tabular}{|c|c|c|c|c|c|c|c|c|c|c|c|c|}
\hline \multirow[b]{2}{*}{ Model } & \multicolumn{3}{|c|}{ Model (1) } & \multicolumn{3}{|c|}{ Model (2) } & \multicolumn{3}{|c|}{ "Model (3) } & \multicolumn{3}{|c|}{ "Model (4) } \\
\hline & $\mathrm{FE}^{\mathrm{a}}$ & $\mathrm{RE}$ & $\begin{array}{c}2 S L S \\
\text { LSDV }\end{array}$ & $\mathrm{FE}$ & $\mathrm{RE}$ & $\begin{array}{c}2 \mathrm{SLS} \\
\mathrm{LSDV}\end{array}$ & $\mathrm{FE}$ & $\mathrm{RE}$ & $\begin{array}{c}2 \mathrm{SLS} \\
\mathrm{LSDV}\end{array}$ & $\mathrm{FE}$ & $\mathrm{RE}$ & $\begin{array}{r}\text { 2SLS } \\
\text { LSDV }\end{array}$ \\
\hline No. Obs. & 251 & 251 & 250 & 247 & 247 & 246 & 239 & 239 & 238 & 239 & 239 & 238 \\
\hline $\mathrm{R}^{2}$ & 0.696 & 0.687 & 0.799 & 0.701 & 0.690 & 0.800 & 0.704 & 0.695 & 0.803 & 0.704 & 0.696 & 0.690 \\
\hline Constant & $\begin{array}{l}21.328 \\
(6.080)\end{array}$ & $\begin{array}{r}23.066 \\
(12.115)\end{array}$ & $\begin{array}{l}28.501 \\
(4.710)\end{array}$ & $\begin{array}{l}18.344 \\
(5.035)\end{array}$ & $\begin{array}{r}21.229 \\
(11.241)\end{array}$ & $\begin{array}{l}26.064 \\
(3.950)\end{array}$ & $\begin{array}{l}17.328 \\
(4.705)\end{array}$ & $\begin{array}{l}19.839 \\
(9.977)\end{array}$ & $\begin{array}{l}25.725 \\
(3.929)\end{array}$ & $\begin{array}{l}17.461 \\
(4.728)\end{array}$ & $\begin{array}{l}19.819 \\
(9.833)\end{array}$ & $\begin{array}{l}11.950 \\
(1.332)\end{array}$ \\
\hline SOES & $\begin{array}{c}-0.115 \\
(-6.115)\end{array}$ & $\begin{array}{r}-0.078 \\
(-4.577)\end{array}$ & $\begin{array}{c}-0.153 \\
(-5.337)\end{array}$ & $\begin{array}{c}-0.091 \\
(-4.207)\end{array}$ & $\begin{array}{c}-0.052 \\
(-2.867)\end{array}$ & $\begin{array}{c}-0.136 \\
(-3.753)\end{array}$ & $\begin{array}{c}-0.094 \\
(-4.368)\end{array}$ & $\begin{array}{c}-0.069 \\
(-3.642)\end{array}$ & $\begin{array}{c}-0.152 \\
(-4.131)\end{array}$ & $\begin{array}{r}-0.095 \\
(-4.391)\end{array}$ & $\begin{array}{r}-0.070 \\
(-3.689)\end{array}$ & $\begin{array}{r}-0.132 \\
(-2.818)\end{array}$ \\
\hline INFL & $\begin{array}{r}0.106 \\
(5.178)\end{array}$ & $\begin{array}{r}0.123 \\
(5.943)\end{array}$ & $\begin{array}{c}0.094 \\
(4.192)\end{array}$ & $\begin{array}{r}0.121 \\
(5.712)\end{array}$ & $\begin{array}{r}0.136 \\
\text { (6.599) }\end{array}$ & $\begin{array}{c}0.104 \\
(4.036)\end{array}$ & $\begin{array}{r}0.127 \\
(5.707)\end{array}$ & $\begin{array}{r}0.142 \\
(6.712)\end{array}$ & $\begin{array}{c}0.108 \\
(4.006)\end{array}$ & $\begin{array}{r}0.130 \\
(5.725)\end{array}$ & $\begin{array}{r}0.144 \\
(6.658)\end{array}$ & $\begin{array}{r}0.162 \\
(3.764)\end{array}$ \\
\hline DISTA & & $\begin{array}{r}1.534 \\
(2.725)\end{array}$ & & & $\begin{array}{r}1.695 \\
(3.155)\end{array}$ & & & $\begin{array}{c}1.484 \\
(2.696)\end{array}$ & & & $\begin{array}{r}1.496 \\
(2.671)\end{array}$ & \\
\hline $\mathrm{SCH}$ & $\begin{array}{r}0.131 \\
(1.608)\end{array}$ & $\begin{array}{r}-0.002 \\
(-0.068)\end{array}$ & $\begin{array}{c}0.176 \\
(0.969)\end{array}$ & $\begin{array}{r}0.149 \\
(1.829)\end{array}$ & $\begin{array}{r}-0.025 \\
(-0.733)\end{array}$ & $\begin{array}{r}0.198 \\
(1.094)\end{array}$ & $\begin{array}{r}0.143 \\
(1.762)\end{array}$ & $\begin{array}{r}-0.011 \\
(-0.305)\end{array}$ & $\begin{array}{c}0.159 \\
(0.869)\end{array}$ & $\begin{array}{r}0.140 \\
(1.724)\end{array}$ & $\begin{array}{r}-0.009 \\
(-0.247)\end{array}$ & $\begin{array}{r}0.483 \\
(2.081)\end{array}$ \\
\hline GDPGR & $\begin{array}{r}0.053 \\
(2.281)\end{array}$ & $\begin{array}{r}0.069 \\
(2.846)\end{array}$ & $\begin{array}{c}0.010 \\
(0.207)\end{array}$ & $\begin{array}{r}0.037 \\
(1.563)\end{array}$ & $\begin{array}{r}0.050 \\
(2.042)\end{array}$ & $\begin{array}{c}0.002 \\
(0.041)\end{array}$ & $\begin{array}{r}0.050 \\
(1.993)\end{array}$ & $\begin{array}{r}0.066 \\
(2.602)\end{array}$ & $\begin{array}{c}0.037 \\
(0.703)\end{array}$ & $\begin{array}{r}0.055 \\
(2.097)\end{array}$ & $\begin{array}{r}0.070 \\
(2.648)\end{array}$ & $\begin{array}{r}0.154 \\
(1.389)\end{array}$ \\
\hline TRADE & & & & 0.050 & 0.060 & 0.029 & 0.049 & 0.056 & 0.020 & 0.049 & 0.056 & 0.053 \\
\hline
\end{tabular}


CEMA Working Paper No. 473

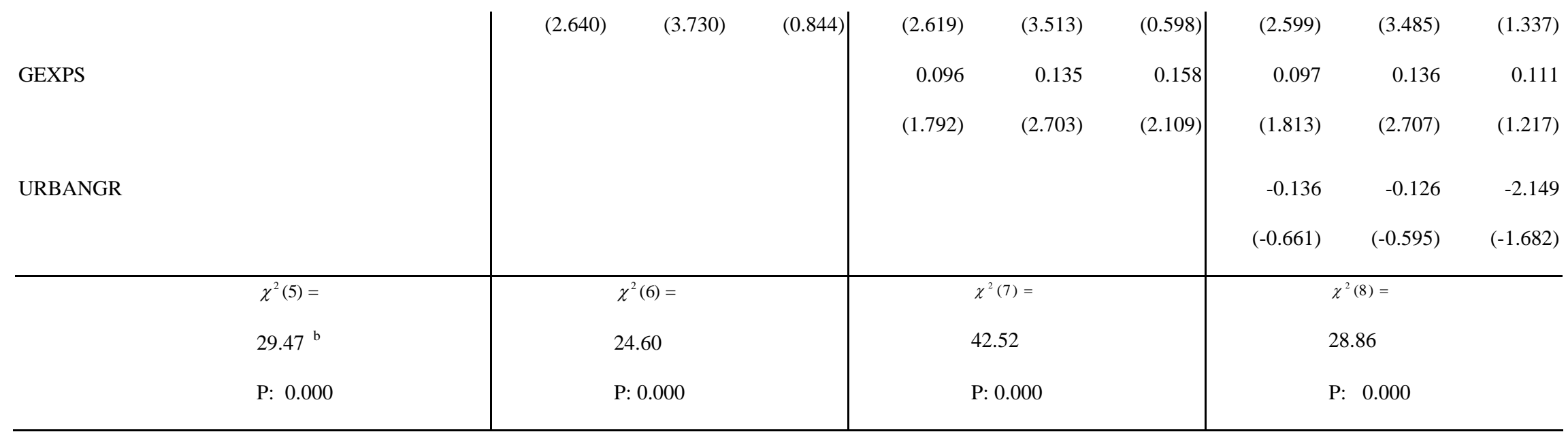

Note. In the parentheses are the t-statistics. See the data appendix for the definitions of the variables.

a. In all these tables, the $\mathrm{R}^{2}$ reported for FE and RE specifications are $\mathrm{R}^{2}$ within. This is appropriate because we focus on the change of the dependent variables.

b. The Hausman's (Chi-Square) test statistics: a large value favors the FE model (instead of RE model); P is the associated P-value. 
Table 6. Determinants of Q5/Q1 (Dependent Variable=Q5/Q1)

\begin{tabular}{|c|c|c|c|c|c|c|c|c|c|c|c|c|}
\hline & \multicolumn{3}{|c|}{ Model (1) } & \multicolumn{3}{|c|}{ Model (2) } & \multicolumn{3}{|c|}{ Model (3) } & \multicolumn{3}{|c|}{ Model (4) } \\
\hline & $\overline{F E}$ & $\mathrm{RE}$ & $\begin{array}{c}\text { 2SLS } \\
\text { LSDV }\end{array}$ & $\mathrm{FE}$ & $\mathrm{RE}$ & $2 \mathrm{SLS}+\mathrm{FE}$ & FE & $\mathrm{RE}$ & $\begin{array}{c}\text { 2SLS } \\
\text { LSDV }\end{array}$ & FE & RE & $\begin{array}{r}\text { 2SLS } \\
\text { LSDV }\end{array}$ \\
\hline No. Obs. & 246 & 246 & 245 & 242 & 242 & 241 & 234 & 234 & 233 & 234 & 234 & 233 \\
\hline $\mathrm{R}^{2}$ within & 0.412 & 0.388 & 0.548 & 0.416 & 0.393 & 0.535 & 0.412 & 0.394 & 0.519 & 0.412 & 0.395 & 0.108 \\
\hline Constant & $\begin{array}{r}2.040 \\
(2.569)\end{array}$ & $\begin{array}{r}2.332 \\
(7.833)\end{array}$ & $\begin{array}{r}4.758 \\
(3.454)\end{array}$ & $\begin{array}{r}1.677 \\
(2.003)\end{array}$ & $\begin{array}{r}2.154 \\
(7.130)\end{array}$ & $\begin{array}{r}4.933 \\
(3.189)\end{array}$ & $\begin{array}{r}1.565 \\
(1.842)\end{array}$ & $\begin{array}{r}2.012 \\
(6.226)\end{array}$ & $\begin{array}{r}4.835 \\
(3.084)\end{array}$ & $\begin{array}{r}1.570 \\
(1.842)\end{array}$ & $\begin{array}{r}2.016 \\
(6.130)\end{array}$ & $\begin{array}{r}0.588 \\
(0.234)\end{array}$ \\
\hline SOES & $\begin{array}{r}-0.021 \\
(-5.024)\end{array}$ & $\begin{array}{r}-0.010 \\
(-3.193)\end{array}$ & $\begin{array}{c}-0.023 \\
(-3.497)\end{array}$ & $\begin{array}{r}-0.018 \\
(-3.726)\end{array}$ & $\begin{array}{r}-0.008 \\
(-2.366)\end{array}$ & $\begin{array}{c}-0.024 \\
(-2.879)\end{array}$ & $\begin{array}{r}-0.019 \\
(-3.784)\end{array}$ & $\begin{array}{r}-0.011 \\
(-2.908)\end{array}$ & $\begin{array}{c}-0.027 \\
(-3.108)\end{array}$ & $\begin{array}{r}-0.019 \\
(-3.778)\end{array}$ & $\begin{array}{r}-0.011 \\
(-2.940)\end{array}$ & $\begin{array}{r}-0.021 \\
(-1.703)\end{array}$ \\
\hline INFL & $\begin{array}{r}0.019 \\
(4.000)\end{array}$ & $\begin{array}{r}0.023 \\
(5.141)\end{array}$ & $\begin{array}{c}0.014 \\
(2.670)\end{array}$ & $\begin{array}{r}0.020 \\
(4.200)\end{array}$ & $\begin{array}{r}0.024 \\
(5.351)\end{array}$ & $\begin{array}{c}0.013 \\
(2.182)\end{array}$ & $\begin{array}{r}0.020 \\
\text { (3.998) }\end{array}$ & $\begin{array}{r}0.024 \\
(5.156)\end{array}$ & $\begin{array}{c}0.013 \\
(2.046)\end{array}$ & $\begin{array}{r}0.021 \\
(3.947)\end{array}$ & $\begin{array}{r}0.024 \\
(4.982)\end{array}$ & $\begin{array}{r}0.029 \\
(2.539)\end{array}$ \\
\hline DISTA & & $\begin{array}{r}0.160 \\
(1.949)\end{array}$ & & & $\begin{array}{r}0.181 \\
(2.214)\end{array}$ & & & $\begin{array}{r}0.163 \\
(1.939)\end{array}$ & & & $\begin{array}{c}0.167 \\
(1.940)\end{array}$ & \\
\hline $\mathrm{SCH}$ & $\begin{array}{r}0.025 \\
(1.376)\end{array}$ & $\begin{array}{r}-0.003 \\
(-0.527)\end{array}$ & $\begin{array}{c}-0.026 \\
(-0.623)\end{array}$ & $\begin{array}{r}0.028 \\
(1.482)\end{array}$ & $\begin{array}{r}-0.005 \\
(-0.934)\end{array}$ & $\begin{array}{c}-0.027 \\
(-0.644)\end{array}$ & $\begin{array}{r}0.027 \\
(1.425)\end{array}$ & $\begin{array}{r}-0.002 \\
(-0.425)\end{array}$ & $\begin{array}{c}-0.034 \\
(-0.792)\end{array}$ & $\begin{array}{r}0.026 \\
(1.415)\end{array}$ & $\begin{array}{r}-0.002 \\
(-0.400)\end{array}$ & $\begin{array}{r}0.059 \\
(0.961)\end{array}$ \\
\hline GDPGR & $\begin{array}{r}0.017 \\
(3.230)\end{array}$ & $\begin{array}{r}0.021 \\
(3.748)\end{array}$ & $\begin{array}{c}0.026 \\
(2.269)\end{array}$ & $\begin{array}{r}0.016 \\
(2.845)\end{array}$ & $\begin{array}{r}0.019 \\
(3.285)\end{array}$ & $\begin{array}{r}0.026 \\
(2.203)\end{array}$ & $\begin{array}{r}0.018 \\
(3.061)\end{array}$ & $\begin{array}{r}0.021 \\
(3.575)\end{array}$ & $\begin{array}{c}0.034 \\
(2.629)\end{array}$ & $\begin{array}{r}0.018 \\
(2.943)\end{array}$ & $\begin{array}{r}0.021 \\
(3.365)\end{array}$ & $\begin{array}{r}0.071 \\
(2.258)\end{array}$ \\
\hline TRADE & & & & 0.006 & 0.006 & -0.002 & 0.006 & 0.005 & -0.004 & 0.006 & 0.005 & 0.006 \\
\hline
\end{tabular}


CEMA Working Paper No. 473

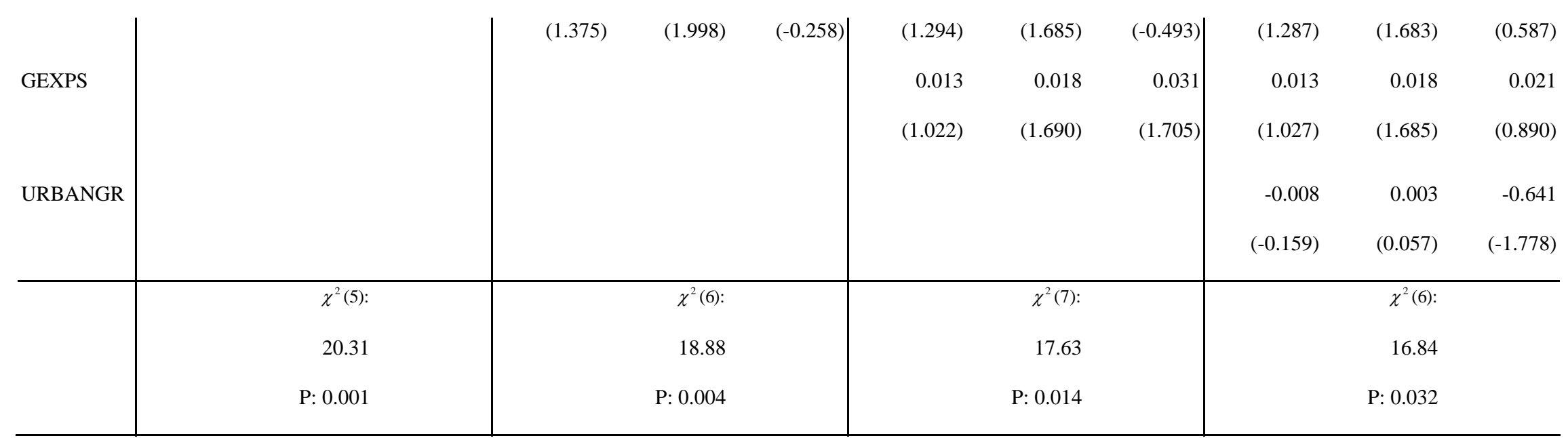

Note. In the parentheses are the t-statistics. See the data appendix for the definitions of the variables. 
Table 7. Determinants of Q5 (Dependent Variable=Q5)

\begin{tabular}{|c|c|c|c|c|c|c|c|c|c|c|c|c|}
\hline & \multicolumn{3}{|c|}{ "Model (1) } & \multicolumn{3}{|c|}{ "Model (2) } & \multicolumn{3}{|c|}{ "Model (3) } & \multicolumn{3}{|c|}{ "Model (4) } \\
\hline & $\overline{\mathrm{FE}}$ & $\mathrm{RE}$ & $\begin{array}{c}\text { 2SLS } \\
\text { LSDV }\end{array}$ & $\mathrm{FE}$ & $\mathrm{RE}$ & $2 \mathrm{SLS}+\mathrm{FE}$ & $\overline{F E}$ & $\mathrm{RE}$ & $\begin{array}{c}\text { 2SLS } \\
\text { LSDV }\end{array}$ & FE & $\mathrm{RE}$ & $\begin{array}{c}\text { 2SLS } \\
\text { LSDV }\end{array}$ \\
\hline No. Obs. & 246 & 246 & 245 & 242 & 242 & 241 & 234 & 234 & 233 & 234 & 234 & 233 \\
\hline $\mathrm{R}^{2}$ within & 0.530 & 0.508 & 0.618 & 0.538 & 0.515 & 0.596 & 0.548 & 0.519 & 0.626 & 0.550 & 0.523 & 0.442 \\
\hline Constant & $\begin{array}{l}27.492 \\
(8.295)\end{array}$ & $\begin{array}{r}30.552 \\
(19.437)\end{array}$ & $\begin{array}{c}45.699 \\
(7.275)\end{array}$ & $\begin{array}{l}25.785 \\
(7.416)\end{array}$ & $\begin{array}{r}29.489 \\
(18.336)\end{array}$ & $\begin{array}{l}48.047 \\
(6.729)\end{array}$ & $\begin{array}{l}27.436 \\
(7.896)\end{array}$ & $\begin{array}{r}30.054 \\
(17.521)\end{array}$ & $\begin{array}{l}47.971 \\
(6.995)\end{array}$ & $\begin{array}{l}27.301 \\
(7.856)\end{array}$ & $\begin{array}{r}30.158 \\
(17.367)\end{array}$ & $\begin{array}{l}33.600 \\
(3.400)\end{array}$ \\
\hline SOES & $\begin{array}{r}-0.110 \\
(-6.224)\end{array}$ & $\begin{array}{r}-0.068 \\
(-4.443)\end{array}$ & $\begin{array}{c}-0.091 \\
(-3.040)\end{array}$ & $\begin{array}{r}-0.095 \\
(-4.644)\end{array}$ & $\begin{array}{r}-0.054 \\
(-3.326)\end{array}$ & $\begin{array}{c}-0.101 \\
(-2.589)\end{array}$ & $\begin{array}{r}-0.089 \\
(-4.390)\end{array}$ & $\begin{array}{r}-0.049 \\
(-2.788)\end{array}$ & $\begin{array}{c}-0.093 \\
(-2.422)\end{array}$ & $\begin{array}{r}-0.088 \\
(-4.326)\end{array}$ & $\begin{array}{r}-0.049 \\
(-2.813)\end{array}$ & $\begin{array}{r}-0.071 \\
(-1.483)\end{array}$ \\
\hline INFL & $\begin{array}{r}0.087 \\
(4.490)\end{array}$ & $\begin{array}{r}0.105 \\
(5.387)\end{array}$ & $\begin{array}{c}0.061 \\
(2.600)\end{array}$ & $\begin{array}{r}0.096 \\
(4.783)\end{array}$ & $\begin{array}{r}0.112 \\
(5.709)\end{array}$ & $\begin{array}{r}0.055 \\
(1.962)\end{array}$ & $\begin{array}{c}0.077 \\
(3.678)\end{array}$ & $\begin{array}{r}0.102 \\
(5.056)\end{array}$ & $\begin{array}{r}0.039 \\
(1.379)\end{array}$ & $\begin{array}{r}0.073 \\
(3.410)\end{array}$ & $\begin{array}{r}0.096 \\
(4.656)\end{array}$ & $\begin{array}{r}0.093 \\
(2.042)\end{array}$ \\
\hline DISTA & & $\begin{array}{r}0.985 \\
(2.182)\end{array}$ & & & $\begin{array}{r}1.080 \\
(2.407)\end{array}$ & & & $\begin{array}{r}1.140 \\
(2.457)\end{array}$ & & & $\begin{array}{r}1.175 \\
(2.495)\end{array}$ & \\
\hline $\mathrm{SCH}$ & $\begin{array}{r}0.148 \\
(1.923)\end{array}$ & $\begin{array}{r}-0.016 \\
(-0.552)\end{array}$ & $\begin{array}{c}-0.303 \\
(-1.608)\end{array}$ & $\begin{array}{r}0.156 \\
(2.004)\end{array}$ & $\begin{array}{r}-0.026 \\
(-0.912)\end{array}$ & $\begin{array}{c}-0.342 \\
(-1.768)\end{array}$ & $\begin{array}{r}0.152 \\
(1.997)\end{array}$ & $\begin{array}{r}-0.030 \\
(-1.003)\end{array}$ & $\begin{array}{c}-0.286 \\
(-1.522)\end{array}$ & $\begin{array}{r}0.155 \\
(2.034)\end{array}$ & $\begin{array}{r}-0.031 \\
(-1.007)\end{array}$ & $\begin{array}{r}0.032 \\
(0.132)\end{array}$ \\
\hline GDPGR & $\begin{array}{r}0.123 \\
(5.518)\end{array}$ & $\begin{array}{r}0.136 \\
(5.857)\end{array}$ & $\begin{array}{c}0.220 \\
(4.172)\end{array}$ & $\begin{array}{r}0.117 \\
(5.080)\end{array}$ & $\begin{array}{r}0.130 \\
(5.391)\end{array}$ & $\begin{array}{r}0.228 \\
(4.139)\end{array}$ & $\begin{array}{c}0.107 \\
(4.541)\end{array}$ & $\begin{array}{r}0.128 \\
(5.182)\end{array}$ & $\begin{array}{r}0.207 \\
(3.643)\end{array}$ & $\begin{array}{r}0.099 \\
(3.954)\end{array}$ & $\begin{array}{r}0.118 \\
(4.559)\end{array}$ & $\begin{array}{r}0.325 \\
(2.632)\end{array}$ \\
\hline TRADE & & & & 0.031 & 0.032 & -0.018 & 0.026 & 0.032 & -0.021 & 0.026 & 0.032 & 0.014 \\
\hline
\end{tabular}


CEMA Working Paper No. 473

\begin{tabular}{|c|c|c|c|c|c|c|c|c|c|c|}
\hline & & (1.736) & (2.199) & $(-0.492)$ & (1.453) & (2.141) & $(-0.583)$ & (1.476) & (2.136) & $(0.359)$ \\
\hline \multirow[t]{2}{*}{ GEXPS } & & & & & -0.113 & -0.048 & -0.122 & -0.116 & -0.052 & -0.156 \\
\hline & & & & & $(-2.249)$ & $(-1.009)$ & $(-1.542)$ & $(-2.310)$ & $(-1.098)$ & $(-1.668)$ \\
\hline \multirow[t]{5}{*}{ URBANGR } & & & & & & & & 0.211 & 0.228 & -2.105 \\
\hline & & & & & & & & (1.087) & (1.112) & $(-1.486)$ \\
\hline & $\chi^{2}(5):$ & & $\chi^{2}(5):$ & & & $\chi^{2}(5):$ & & & $\chi^{2}(5):$ & \\
\hline & 32.06 & & 31.87 & & & 22.90 & & & 21.81 & \\
\hline & P: 0.000 & & P: 0.000 & & & P: 0.002 & & & P: 0.005 & \\
\hline
\end{tabular}

Note. In the parentheses are the t-statistics. See the data appendix for the definitions of the variables. 
Table 8. Determinants of Q1 (Dependent Variable=Q1)

\begin{tabular}{|c|c|c|c|c|c|c|c|c|c|c|c|c|}
\hline & \multicolumn{3}{|c|}{ Model (1) } & \multicolumn{3}{|c|}{ "Model (2) } & \multicolumn{3}{|c|}{ Model (3) } & \multicolumn{3}{|c|}{ "Model (4) } \\
\hline & $\mathrm{FE}$ & $\mathrm{RE}$ & $\begin{array}{c}\text { 2SLS } \\
\text { LSDV }\end{array}$ & $\overline{F E}$ & $\mathrm{RE}$ & $2 \mathrm{SLS}+\mathrm{FE}$ & $\mathrm{FE}$ & RE & $\begin{array}{c}\text { 2SLS } \\
\text { LSDV }\end{array}$ & $\overline{F E}$ & $\mathrm{RE}$ & $\begin{array}{r}\text { 2SLS } \\
\text { LSDV }\end{array}$ \\
\hline No. Obs. & 246 & 246 & 245 & 242 & 242 & 241 & 234 & 234 & 233 & 234 & 234 & 233 \\
\hline $\mathrm{R}^{2}$ within & 0.469 & 0.456 & 0.600 & 0.475 & 0.463 & 0.589 & 0.470 & 0.459 & 0.571 & 0.471 & 0.460 & 0.192 \\
\hline Constant & $\begin{array}{l}13.474 \\
(5.470)\end{array}$ & $\begin{array}{r}12.651 \\
(12.341)\end{array}$ & $\begin{array}{r}4.630 \\
(1.055)\end{array}$ & $\begin{array}{l}15.001 \\
(5.804)\end{array}$ & $\begin{array}{r}13.117 \\
(12.268)\end{array}$ & $\begin{array}{r}4.115 \\
(0.833)\end{array}$ & $\begin{array}{l}15.032 \\
(5.745)\end{array}$ & $\begin{array}{r}13.319 \\
(11.697)\end{array}$ & $\begin{array}{r}4.424 \\
(0.880)\end{array}$ & $\begin{array}{l}14.989 \\
(5.713)\end{array}$ & $\begin{array}{r}13.333 \\
(11.510)\end{array}$ & $\begin{array}{l}18.507 \\
(2.275)\end{array}$ \\
\hline SOES & $\begin{array}{r}0.068 \\
(5.208)\end{array}$ & $\begin{array}{r}0.043 \\
(4.027)\end{array}$ & $\begin{array}{r}0.070 \\
(3.365)\end{array}$ & $\begin{array}{r}0.056 \\
(3.674)\end{array}$ & $\begin{array}{r}0.036 \\
(3.217)\end{array}$ & $\begin{array}{c}0.079 \\
(2.919)\end{array}$ & $\begin{array}{r}0.056 \\
(3.646)\end{array}$ & $\begin{array}{r}0.040 \\
(3.248)\end{array}$ & $\begin{array}{c}0.087 \\
(3.075)\end{array}$ & $\begin{array}{r}0.056 \\
(3.659)\end{array}$ & $\begin{array}{r}0.041 \\
(3.278)\end{array}$ & $\begin{array}{r}0.065 \\
(1.648)\end{array}$ \\
\hline INFL & & & -0.031 & & & & & & -0.027 & -0.060 & & -0.081 \\
\hline DISTA & $(-3.650)$ & $\begin{array}{r}(-4.494) \\
-0.540 \\
(-1.871)\end{array}$ & $(-1.916)$ & $(-4.021)$ & $\begin{array}{r}(-4.698) \\
-0.614 \\
(-2.085)\end{array}$ & $(-1.457)$ & $(-3.720)$ & $\begin{array}{r}(-4.483) \\
-0.569 \\
(-1.879)\end{array}$ & $(-1.322)$ & $(-3.734)$ & $\begin{array}{r}(-4.413) \\
-0.576 \\
(-1.867)\end{array}$ & $(-2.160)$ \\
\hline $\mathrm{SCH}$ & $\begin{array}{r}-0.061 \\
(-1.071)\end{array}$ & $\begin{array}{r}0.011 \\
(0.592)\end{array}$ & $\begin{array}{c}0.132 \\
(1.003)\end{array}$ & $\begin{array}{r}-0.071 \\
(-1.232)\end{array}$ & $\begin{array}{r}0.018 \\
(0.958)\end{array}$ & $\begin{array}{c}0.124 \\
(0.924)\end{array}$ & $\begin{array}{r}-0.068 \\
(-1.182)\end{array}$ & $\begin{array}{r}0.015 \\
(0.751)\end{array}$ & $\begin{array}{r}0.137 \\
(0.995)\end{array}$ & $\begin{array}{r}-0.067 \\
(-1.163)\end{array}$ & $\begin{array}{r}0.014 \\
(0.699)\end{array}$ & $\begin{array}{r}-0.173 \\
(-0.867)\end{array}$ \\
\hline GDPGR & $\begin{array}{r}-0.067 \\
(-4.054)\end{array}$ & $\begin{array}{r}-0.074 \\
(-4.328)\end{array}$ & $\begin{array}{c}-0.126 \\
(-3.421)\end{array}$ & $\begin{array}{r}-0.059 \\
(-3.478)\end{array}$ & $\begin{array}{r}-0.067 \\
(-3.788)\end{array}$ & $\begin{array}{c}-0.127 \\
(-3.330)\end{array}$ & $\begin{array}{r}-0.061 \\
(-3.432)\end{array}$ & $\begin{array}{r}-0.069 \\
(-3.831)\end{array}$ & $\begin{array}{c}-0.146 \\
(-3.507)\end{array}$ & $\begin{array}{r}-0.064 \\
(-3.392)\end{array}$ & $\begin{array}{r}-0.071 \\
(-3.718)\end{array}$ & $\begin{array}{r}-0.267 \\
(-2.625)\end{array}$ \\
\hline TRADE & & & & -0.024 & -0.018 & 0.015 & -0.022 & -0.017 & 0.021 & -0.022 & -0.017 & -0.012 \\
\hline
\end{tabular}


CEMA Working Paper No. 473

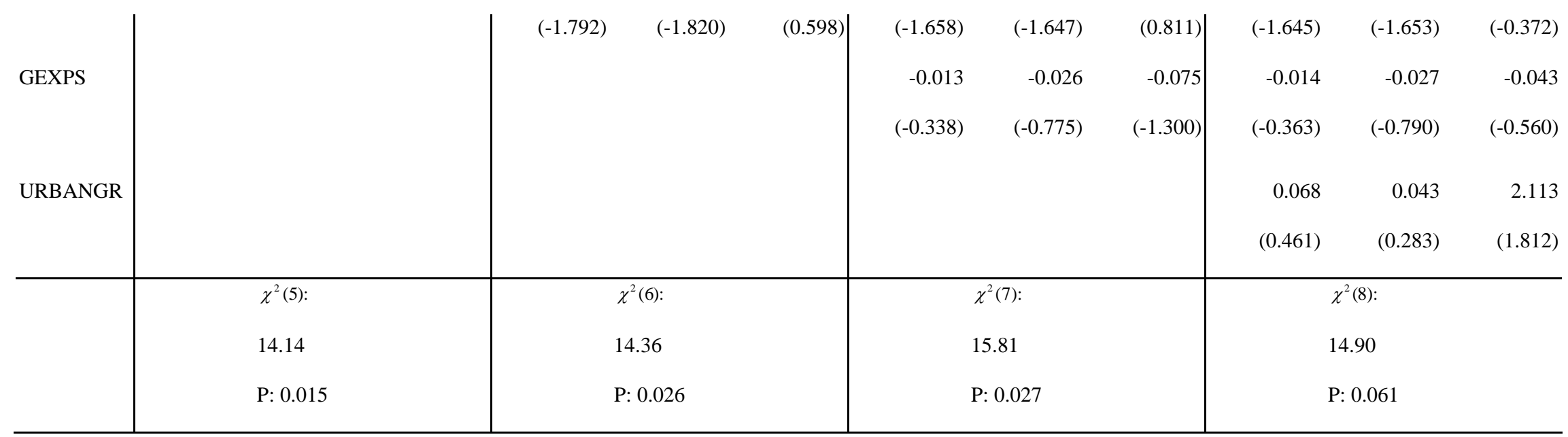

Note. In the parentheses are the t-statistics. See the data appendix for the definitions of the variables. 
Table 9. Determinants of Q34 (Dependent Variable=Q34)

\begin{tabular}{|c|c|c|c|c|c|c|c|c|c|c|c|c|}
\hline & \multicolumn{3}{|c|}{ "Model (1) } & \multicolumn{3}{|c|}{ "Model (2) } & \multicolumn{3}{|c|}{ "Model (3) } & \multicolumn{3}{|c|}{ "Model (4) } \\
\hline & $\overline{\mathrm{FE}}$ & $\mathrm{RE}$ & $\begin{array}{c}\text { 2SLS } \\
\text { LSDV }\end{array}$ & FE & $\mathrm{RE}$ & $2 \mathrm{SLS}+\mathrm{FE}$ & $\overline{F E}$ & $\mathrm{RE}$ & $\begin{array}{c}\text { 2SLS } \\
\text { LSDV }\end{array}$ & $\mathrm{FE}$ & $\mathrm{RE}$ & $\begin{array}{c}\text { 2SLS } \\
\text { LSDV }\end{array}$ \\
\hline No. Obs. & 246 & 246 & 245 & 242 & 242 & 241 & 234 & 234 & 233 & 234 & 234 & 233 \\
\hline $\mathrm{R}^{2}$ within & 0.855 & 0.852 & 0.851 & 0.858 & 0.853 & 0.849 & 0.854 & 0.849 & 0.844 & 0.856 & 0.850 & 0.837 \\
\hline Constant & $\begin{array}{r}42.999 \\
(22.501)\end{array}$ & $\begin{array}{r}41.053 \\
(66.907)\end{array}$ & $\begin{array}{r}37.306 \\
(11.070)\end{array}$ & $\begin{array}{r}42.165 \\
(21.094)\end{array}$ & $\begin{array}{r}41.299 \\
(64.872)\end{array}$ & $\begin{array}{c}36.719 \\
(9.717)\end{array}$ & $\begin{array}{r}41.921 \\
(20.387)\end{array}$ & $\begin{array}{r}41.400 \\
(59.703)\end{array}$ & $\begin{array}{c}36.526 \\
(9.538)\end{array}$ & $\begin{array}{r}42.024 \\
(20.476)\end{array}$ & $\begin{array}{r}41.319 \\
(58.605)\end{array}$ & $\begin{array}{l}34.382 \\
(7.442)\end{array}$ \\
\hline SOES & $\begin{array}{r}0.003 \\
(0.294)\end{array}$ & $\begin{array}{r}-0.012 \\
(-1.742)\end{array}$ & $\begin{array}{c}-0.016 \\
(-0.969)\end{array}$ & $\begin{array}{r}0.009 \\
(0.741)\end{array}$ & $\begin{array}{r}-0.014 \\
(-1.995)\end{array}$ & $\begin{array}{c}-0.019 \\
(-0.912)\end{array}$ & $\begin{array}{r}0.007 \\
(0.625)\end{array}$ & $\begin{array}{r}-0.012 \\
(-1.414)\end{array}$ & $\begin{array}{r}-0.025 \\
(-1.169)\end{array}$ & $\begin{array}{r}0.007 \\
(0.548)\end{array}$ & $\begin{array}{r}-0.012 \\
(-1.388)\end{array}$ & $\begin{array}{r}-0.022 \\
(-0.974)\end{array}$ \\
\hline INFL & $\begin{array}{r}0.000 \\
(0.025)\end{array}$ & $\begin{array}{r}-0.007 \\
(-0.652)\end{array}$ & $\begin{array}{c}-0.003 \\
(-0.273)\end{array}$ & $\begin{array}{r}0.003 \\
(0.273)\end{array}$ & $\begin{array}{r}-0.008 \\
(-0.772)\end{array}$ & $\begin{array}{c}-0.004 \\
(-0.294)\end{array}$ & $\begin{array}{r}0.007 \\
(0.552)\end{array}$ & $\begin{array}{r}-0.007 \\
(-0.665)\end{array}$ & $\begin{array}{c}-0.001 \\
(-0.040)\end{array}$ & $\begin{array}{r}0.010 \\
(0.810)\end{array}$ & $\begin{array}{r}-0.004 \\
(-0.321)\end{array}$ & $\begin{array}{r}0.008 \\
(0.358)\end{array}$ \\
\hline DISTA & & $\begin{array}{c}-0.013 \\
(-0.079)\end{array}$ & & & $\begin{array}{r}-0.032 \\
(-0.189)\end{array}$ & & & $\begin{array}{c}-0.033 \\
(-0.183)\end{array}$ & & & $\begin{array}{r}-0.046 \\
(-0.250)\end{array}$ & \\
\hline $\mathrm{SCH}$ & $\begin{array}{r}-0.063 \\
(-1.429)\end{array}$ & $\begin{array}{r}0.011 \\
(1.083)\end{array}$ & $\begin{array}{c}0.105 \\
(1.040)\end{array}$ & $\begin{array}{r}-0.055 \\
(-1.241)\end{array}$ & $\begin{array}{r}0.012 \\
(1.073)\end{array}$ & $\begin{array}{c}0.131 \\
(1.278)\end{array}$ & $\begin{array}{r}-0.056 \\
(-1.251)\end{array}$ & $\begin{array}{r}0.009 \\
(0.773)\end{array}$ & $\begin{array}{c}0.118 \\
(1.123)\end{array}$ & $\begin{array}{r}-0.059 \\
(-1.302)\end{array}$ & $\begin{array}{r}0.010 \\
(0.840)\end{array}$ & $\begin{array}{r}0.165 \\
(1.456)\end{array}$ \\
\hline GDPGR & $\begin{array}{r}-0.014 \\
(-1.058)\end{array}$ & $\begin{array}{r}-0.022 \\
(-1.774)\end{array}$ & $\begin{array}{c}-0.022 \\
(-0.762)\end{array}$ & $\begin{array}{r}-0.020 \\
(-1.476)\end{array}$ & $\begin{array}{r}-0.023 \\
(-1.793)\end{array}$ & $\begin{array}{c}-0.024 \\
(-0.824)\end{array}$ & $\begin{array}{r}-0.018 \\
(-1.321)\end{array}$ & $\begin{array}{r}-0.026 \\
(-1.925)\end{array}$ & $\begin{array}{c}-0.013 \\
(-0.410)\end{array}$ & $\begin{array}{r}-0.012 \\
(-0.800)\end{array}$ & $\begin{array}{r}-0.020 \\
(-1.410)\end{array}$ & $\begin{array}{r}0.006 \\
(0.109)\end{array}$ \\
\hline TRADE & & & & 0.011 & -0.005 & -0.005 & 0.011 & -0.005 & -0.007 & 0.010 & -0.004 & -0.002 \\
\hline
\end{tabular}


CEMA Working Paper No. 473

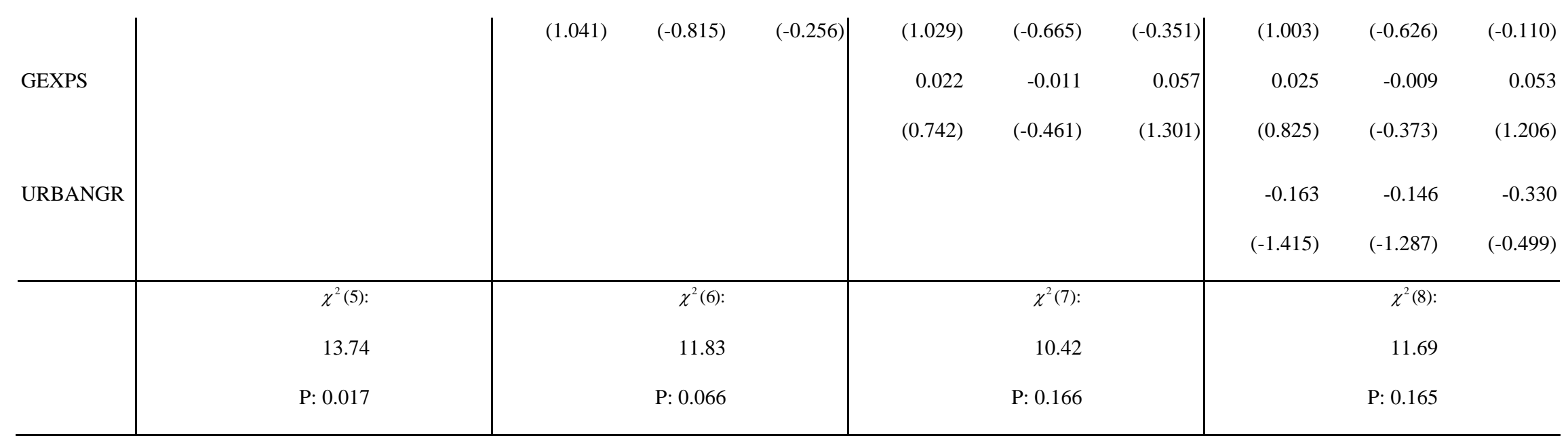

Note. In the parentheses are the t-statistics. See the data appendix for the definitions of the variables. 